Article

\title{
Evaluating Vulnerability of Central Asian Water Resources under Uncertain Climate and Development Conditions: The Case of the Ili-Balkhash Basin
}

\author{
Tesse de Boer ${ }^{1, *}$, Homero Paltan ${ }^{1,2}$, Troy Sternberg ${ }^{1}$ and Kevin Wheeler ${ }^{3}$ (D) \\ 1 School of Geography and the Environment, University of Oxford, Oxford OX1 3QY, UK; \\ homero.paltanlopez@ouce.ox.ac.uk (H.P.); troy.sternberg@geog.ox.ac.uk (T.S.) \\ 2 Institute of Geography, Universidad San Francisco de Quito, Quito 170901, Ecuador \\ 3 Environmental Change Institute, University of Oxford, Oxford OX1 3QY, UK; kevin.wheeler@ouce.ox.ac.uk \\ * Correspondence: tesseadboer@live.nl
}

Citation: de Boer, T.; Paltan, H.; Sternberg, T.; Wheeler, K. Evaluating Vulnerability of Central Asian Water Resources under Uncertain Climate and Development Conditions: The Case of the Ili-Balkhash Basin. Water 2021, 13, 615. https://doi.org/ 10.3390/w13050615

Academic Editor: Steven G. Pueppke

Received: 29 January 2021

Accepted: 21 February 2021

Published: 26 February 2021

Publisher's Note: MDPI stays neutral with regard to jurisdictional claims in published maps and institutional affiliations.

Copyright: (c) 2021 by the authors. Licensee MDPI, Basel, Switzerland. This article is an open access article distributed under the terms and conditions of the Creative Commons Attribution (CC BY) license (https:// creativecommons.org/licenses/by/ $4.0 /)$.

\begin{abstract}
The Ili-Balkhash basin (IBB) is considered a key region for agricultural development and international transport as part of China's Belt and Road Initiative (BRI). The IBB is exemplary for the combined challenge of climate change and shifts in water supply and demand in transboundary Central Asian closed basins. To quantify future vulnerability of the IBB to these changes, we employ a scenario-neutral bottom-up approach with a coupled hydrological-water resource modelling set-up on the RiverWare modelling platform. This study focuses on reliability of environmental flows under historical hydro-climatic variability, future hydro-climatic change and upstream water demand development. The results suggest that the IBB is historically vulnerable to environmental shortages, and any increase in water consumption will increase frequency and intensity of shortages. Increases in precipitation and temperature improve reliability of flows downstream, along with water demand reductions upstream and downstream. Of the demand scenarios assessed, extensive water saving is most robust to climate change. However, the results emphasize the competition for water resources among up- and downstream users and between sectors in the lower Ili, underlining the importance of transboundary water management to mitigate cross-border impacts. The modelling tool and outcomes may aid decision-making under the uncertain future in the basin.
\end{abstract}

Keywords: climate change; belt and road initiative; water resources; central Asia

\section{Introduction}

Transboundary closed or endorheic river and lake systems are among the most vulnerable to changes in demand and supply, exemplified by the drastic reduction in surface area and volume of the Aral Sea, Lake Urmia and Lake Chad in the last decades [1]. The closed basins of Central Asia are particularly vulnerable; climate change threatens water supply from glacier systems and increases evaporative losses, while demand is rising [2,3]. Uncertain climate projections, human decision making and natural variability of hydrological systems complicate risk management [4]. The endorheic transboundary Ili-Balkhash Basin (IBB) illustrates these challenges.

The Ili River supplies 70-80\% of annual inflows to Lake Balkhash, currently the largest endorheic freshwater lake (average volume 106 billion cubic metres (BCM) in Central Asia since the desiccation of the Aral Sea [5-7]. The Ili River is the longest river shared between China (Xinjiang Province) and South East Kazakhstan (see Figure 1), taking water from the Tian Shan mountains in Xinjiang to the Kazakh steppe. In the dry continental Central Asian region, the Ili is an important source of water for the growing cities, irrigated agriculture, energy industries and the RAMSAR protected wetlands in the Ili Delta [8-11]. The reliability of Ili River flows to downstream Kazakhstan and conservation of Lake Balkhash, are the focal points of Sino-Kazakh hydro politics; thus far, parties have 
not established a volumetric water allocation agreement [12,13]. Recent political and climatic changes fuel concerns over the future of Lake Balkhash, as competition for water resources between countries and sectors appears to be increasing $[6,14,15]$.

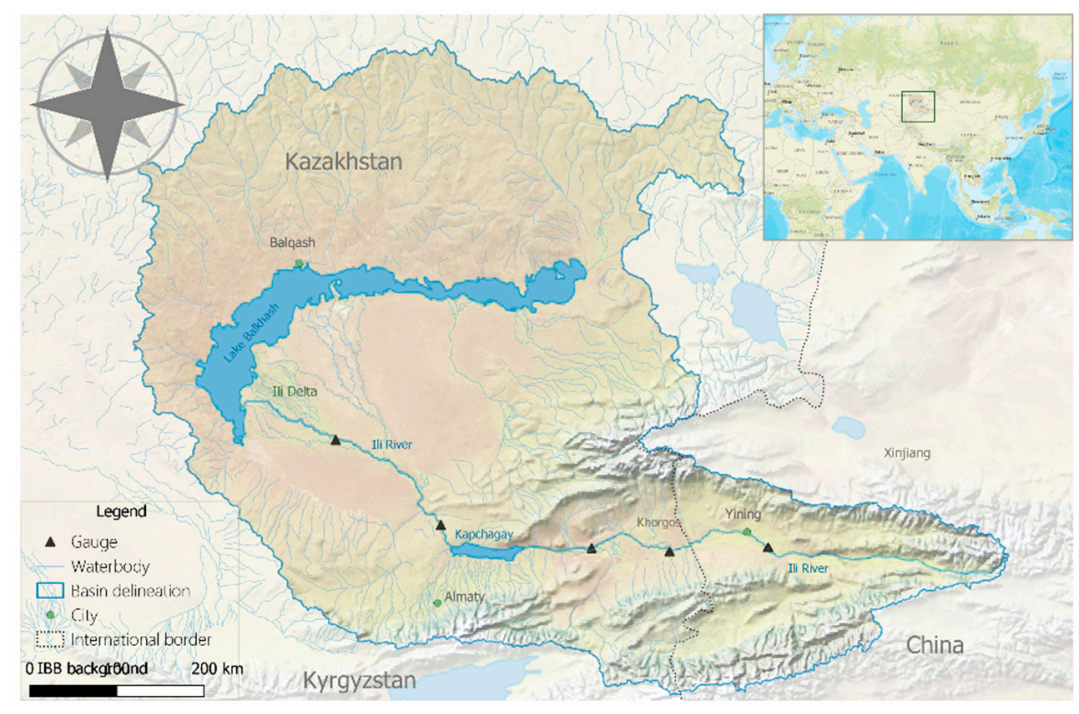

Figure 1. Map of the Ili-Balkhash Basin.

At the crossroads between West China and Central Asia, the IBB has a long history of trade and (irrigated) agriculture [16]. However, recently socio-economic development in the basin has accelerated, in turn increasing uncertainty about its future. The region is receiving extensive (foreign) investment for infrastructure, food production and hydropower development through the Silk Road Economic Belt (SREB), part of the Belt and Road Initiative (BRI) championed by China since 2013 and earlier through the western development policies $[17,18]$. The $\$ 1$ trillion BRI, pitched as a 'win-win' programme, has become contentious in Central Asia. Whilst embraced by governments, public sentiment perceives agricultural investments as land grabs. Though research shows BRI investment does not affect food security in Kazakhstan [19], widespread sinophobia turns communities against the initiative [20]. Here agriculture in the arid north-west of China is undergoing rapid modernisation and organisational changes under the BRI agenda [18,21,22]. Between 2000 and 2015 , cropland under irrigation increased by $17 \%$ in the Chinese upstream section of the basin, accompanied by a marked increase in water consumption $[7,23]$. Estimates suggest that agriculture consumes $90 \%$ of water in the basin, yet the estimates of the extent of agricultural land use in the Chinese Ili basin are limited and vary significantly due to access restrictions and data limitations [7,23-25]. Therefore, discussions over planned (agricultural) development for the next decades remain speculative, impeding water management decision-making.

The IBB is also a climate-sensitive region. Although there are no studies on potential implications of global climate change for water management in the Ili basin, regional assessments offer some insight. Overall, climate projections from Global Circulation Models (GCMs) predict at least $1{ }^{\circ} \mathrm{C}$ of warming by 2060 relative to 1986-2005, particularly in winter [26]. Warming is already affecting the basins hydrology, with glacial melt accelerating and shifts to earlier meltwater peaks [27]. For precipitation, projections are less in agreement and GCM, IPCC regional assessments, and studies in adjacent basins suggest rainfall may decrease, remain stable or even slightly increase, depending on the GCM used [2,26,28]. GCM performance across Central Asia is also debated, as the mountainous topography and lack of field measurement data complicate down-scaling [29,30]. While changes in temperature and rainfall are likely to affect river flows, the diverging projections and methodological limitations introduce uncertainties on the magnitude of such changes, thus complicating adaptation strategies. 
Although previous research provides insights into the potential threats to water security in the basin $[6,7,13,15,31]$, and given the pressing issues that the catchment and region face, no study has explored the combination of natural hydrological variability, climate change, and demand change. Given the wide range of uncertainties in understanding future climatic and demand pathways, we employ a scenario-neutral decision-scaling approach to quantify future vulnerability and reliability of the IBB [32,33]. In contrast to top-down downscaling in vulnerability analysis, this methodology uses a bottom-up approach, which tests a wide range of potential futures to explore vulnerabilities of a system [33-36]. Furthermore, this study is the first to evaluate vulnerabilities within an uncertainty approach in a river basin in Central Asia specifically and to explicitly integrate transboundary water risks in the BRI context. In doing so, this study offers insight into a wide range of potential stressors on the basin in the near future to inform water management decisions.

\section{Study Area}

The Ili-Balkhash basin has a total catchment area of $140,000 \mathrm{~km}^{2}$. The Ili River is $1492 \mathrm{~km}$ long, and receives a combination of snow melt, glacial melt, and rainfall with peak flows during the growing season (June, July and August) [5,27]. The downstream region is arid (average precipitation $120 \mathrm{~mm}$ ), whereas the mountainous upper Ili is semi-arid with a strong precipitation and temperature gradient following topography $(200 \mathrm{~mm} /$ year in the lower valley to $800 \mathrm{~mm} /$ year in the highest region) [37-39]. As average precipitation in Xinjiang province is $165 \mathrm{~mm}$ /year, the Ili Valley is considered one of the most fertile areas of the arid north-west China $[16,38,39]$.

The Ili supplies water to competing sectors. The Kapchagay dam (364 MW; average length of reservoir $140 \mathrm{~km}$, maximum capacity $28.1 \mathrm{BCM}$ ) provides energy to one-fifth of the Kazakh population [14,40,41]. The Ili also supports the majority of irrigated agriculture in Kazakhstan and Xinjiang, although currently irrigated agriculture in the lower basin is small compared to the Chinese Ili Valley [16]. The maximal potentially irrigated land in the Chinese Ili region is estimated at $12,000 \mathrm{~km}^{2}$ [42], yet there is disagreement on the current area under irrigation (7350 to $8085 \mathrm{~km}^{2}$ in 2014/2015) in the Ili Prefecture due to limited data availability and reporting [7,23-25].

In an attempt to mitigate potential transboundary environmental impacts of domestic development, the local Ili government published an "Environmental Protection Plan" (EPP) in 2015 [43]. The EPP states that by 2030 water consumption for direct production and living in the Chinese Ili basin should be limited to 7.122 BCM [43]. The lower reaches of the Ili, from the Kapchagay reservoir to Lake Balkhash, form a fertile delta with RAMSAR protected status [8].

\section{Materials and Methodology}

\subsection{General Methodology}

To assess the impacts of historical hydrological variability, hydro-climatic change, and potential upstream water consumption shifts on downstream water security, this study uses a scenario-based modelling approach (see Figure 2). Using the RiverWare water resource modelling tool, we explore the outcomes for downstream water security using six upstream water consumption scenarios combined with two sets of river runoff simulations, representing historical and potential climate change conditions. Climate change-representative flows for the Ili are generated through a simple rainfall-runoff model (ABCDE) using a scenario-neutral approach [26]. Downstream water security is evaluated through reliability and robustness of environmental flows, irrigation water shortages and flow duration curves for the lower Ili. 


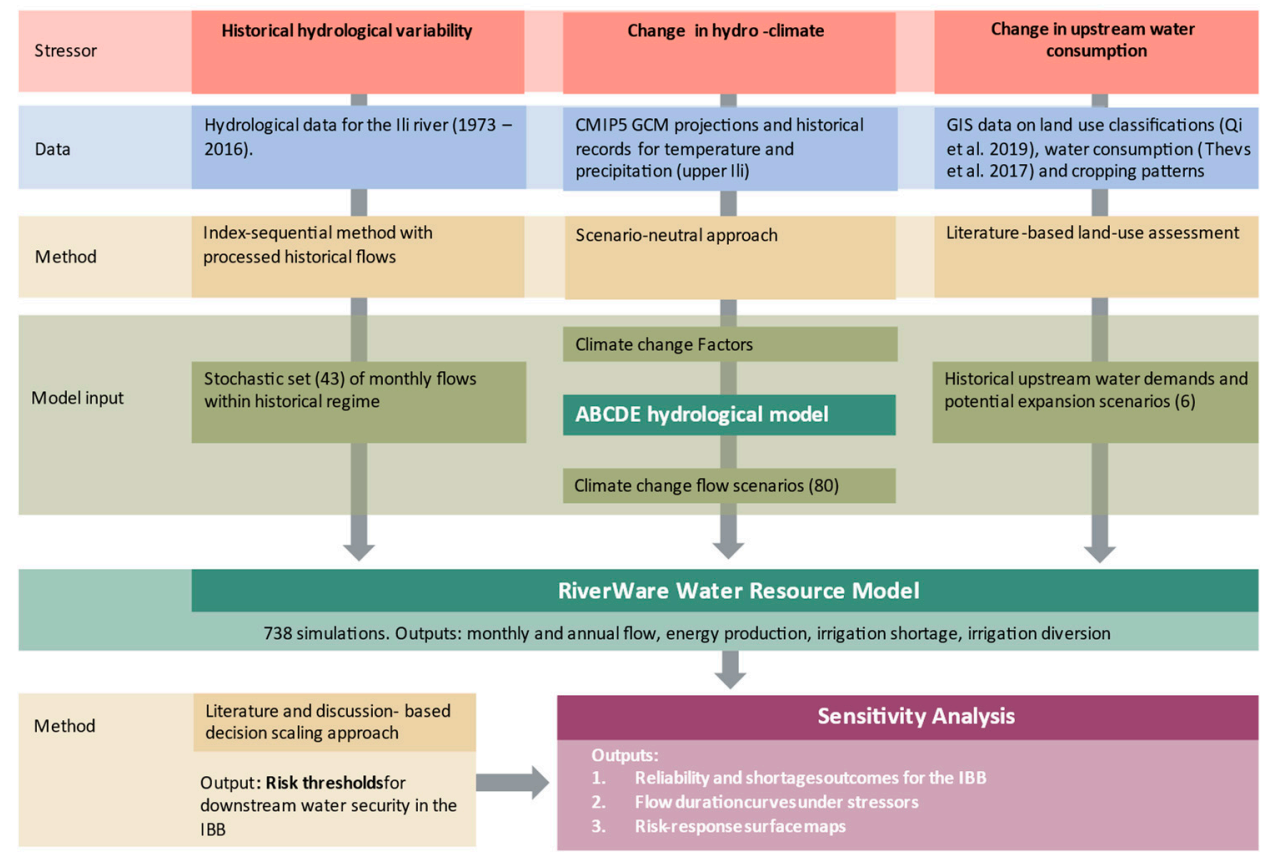

Figure 2. Graphical overview of methodology.

\subsection{Hydro-Climate Simulations}

\subsubsection{Historical Hydro-Climatic Regime}

Two sets of hydrologic inflows drive the RiverWare model, representing historical conditions ( 43 traces) and potential future climate change ( 80 traces), respectively (see Figure 3 ). First, a stochastic set of historical flows was generated with the index-sequential method (ISM) in RiverWare [44]. Historical data from 1973-2016 drives the RiverWare model, covering a wide range of both dry and wet years. The 43 hydrologic traces generated using ISM represent a stochastic set of scenarios of historical hydro-climate.

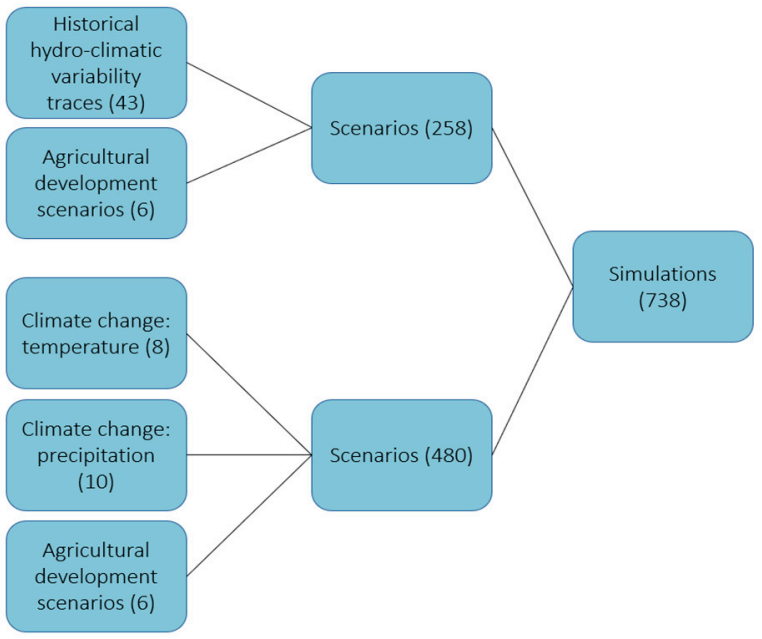

Figure 3. Schematic of scenario combinations.

\subsubsection{Future Climate Change}

Second, a set of 80 scenarios representing future change in temperature and precipitation were generated. Using the scenario-neutral methodology [32], adapted to data-scarce regions [45], we calculated the change between baseline (1986-2005) and 2020-2060, using the monthly median of change factors of the 2020-2039 and 2040-2059 blocks of CMIP5 projections to address decadal variability and sampling uncertainty [45]. To compensate for any potential loss of variability, the range from the 10th to the 90th percentile projected 
change by 2060 for RCP2.6 $\left(0{ }^{\circ} \mathrm{C}\right.$ to $4.3{ }^{\circ} \mathrm{C} ;-40 \%$ to $\left.+41 \%\right)$ to $\mathrm{RCP} 8.5\left(0.5{ }^{\circ} \mathrm{C}\right.$ to $4.85{ }^{\circ} \mathrm{C}$; $-34 \%$ to $+44 \%$ ) were considered. As GCM projections suffer from aforementioned limitations in Central Asia, the simulated scenarios extend slightly beyond GCM projections (See Table 1). These changes were applied to historical precipitation and temperature records and used as input to the rainfall-runoff model.

Table 1. Climatic change range ( 8 temperature and 10 precipitation intervals which form 80 potential climate combinations).

\begin{tabular}{cccc}
\hline Uncertain Parameter & Min & Max & Changes Interval \\
\hline Temperature & $-1{ }^{\circ} \mathrm{C}$ & $6{ }^{\circ} \mathrm{C}$ & $1{ }^{\circ} \mathrm{C}$ \\
\hline Precipitation & $-50 \%$ & $+50 \%$ & $11 \%$ \\
\hline
\end{tabular}

\subsection{Rainfall-Runoff Model}

To simulate the response of Ili streamflow to changes in precipitation and temperature in the catchment, a simple conceptual hydrological model, the ABCD(E) model [46], was used. The $A B C D(E)$ model provided river flow inputs to the RiverWare water management model, both of which were calibrated in sequential steps. The ABCD $(E)$ model is useful for climate impact assessments because of its speed, accuracy, and simplicity [47,48]. This study uses an excel-based version, with monthly timestep input data for the upper Ili region (coordinates: 44-47 N; 72-83 E) for inflow location "Yamadu" (see Figure 1).

Historical timeseries for precipitation (mm/month) and maximum, minimum, and average temperature $\left({ }^{\circ} \mathrm{C}\right)$ were downloaded through the KNMI climate data portal (climexp.knmi.nl) for the period January 2004 to December 2016, based on availability of hydrological data from the Ili River for calibration. The five calibration parameters of the $A B C D(E)$ model are (1) unsaturated soil runoff and recharge " $a$ ", (2) the saturation level of soils " $b$ ', (3) ratio of groundwater recharge to surface runoff " $c$ ", (4) rate of groundwater recharge " $\mathrm{d}$ " and (5) a temperature-based snow accumulation and melt component "e". Calibration and validation of the $\mathrm{ABCD}(\mathrm{E})$ model was performed by calculating the Nash-Sutcliffe Efficiency (NSE) and ratio of the root-mean-square-error (RMSE) to standard deviation of the observations (RSR) for river flow predictions based on the climatic variables compared to historical records [49]. Calibration for January 2004-December 2011 (NSE: 0.84; RSR 0.7) and validation for January 2012-December 2016 (NSE 0.82; RSR 0.73) resulted in good to satisfactory results.

After applying the change factors, the $\mathrm{ABCD}(\mathrm{E})$ model generated a set of 80 inflows for the Ili River for 2020-2060, representing river runoff under precipitation and temperature change. It should be noted that all parameters (abdce) were assumed to remain stable due to data limitations. Overall, the model performs acceptably on a monthly timestep, capturing seasonality and low flows, which are relevant to inform the aims of this study. However, it is important to note that our modelling framework does not capture submonthly peak flows that might occur on a daily or weekly basis.

\subsection{Water Resource Model}

For the purpose of assessing risks and mitigation strategies in the Ili-Balkhash Basin, RiverWare modelling software was chosen [50]. The generalized water resource modelling platform RiverWare simulates complex system interactions based on mass balance equations and allows the user to explore implications of future uncertainties and trade-offs through flexibility in the physical parameters and operating policies [50]. For example, it is widely used in the Colorado River basin for management and future planning, and in the Nile Basin for transboundary risk-based assessments [50-53]. The model of the Ili basin is a monthly scoping model (see Figure 4; modelled characteristics outlined in Appendices $\mathrm{A}$ and $\mathrm{B}$ ). 


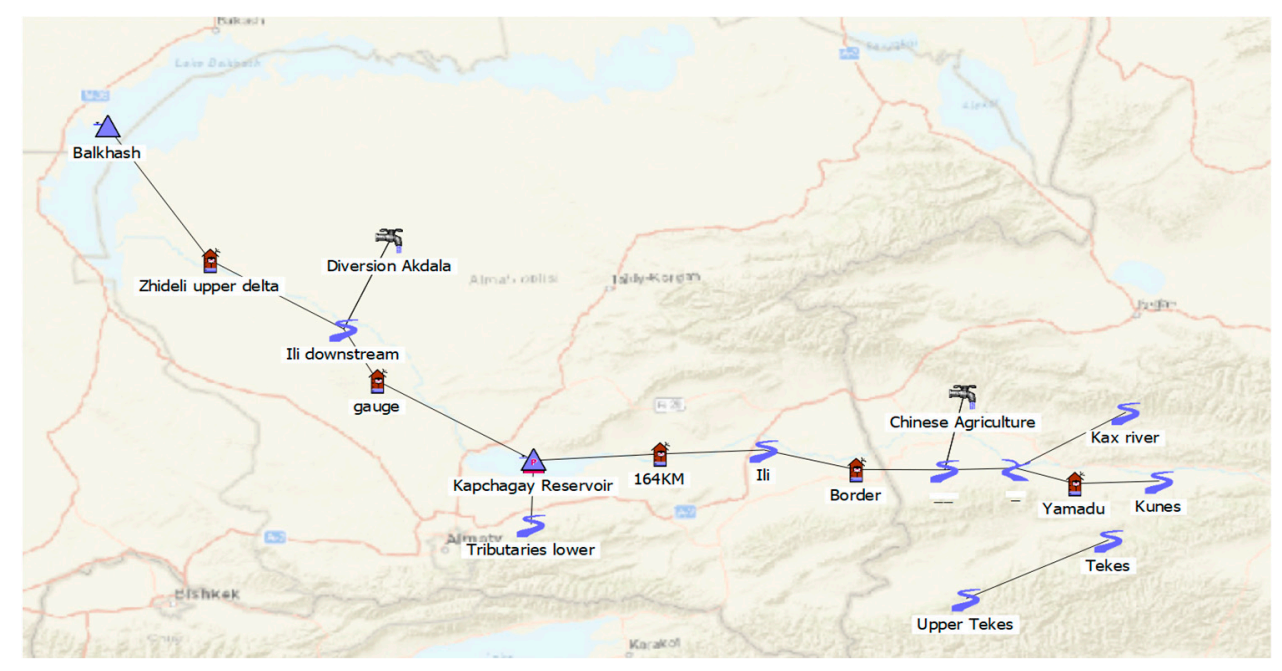

Figure 4. Schematic overview of RiverWare workspace of the Ili Basin model.

Historical hydrologic input for the model set-up was based on monthly historical flow records at five sites along the Kazakh Ili from KazHydromet. Data gaps were filled by regression and interpolation based on flows upstream, downstream and from previous years. As no hydrological reports for the Ili Prefecture are available, a naturalised set (unregulated and devoid of anthropogenic influences) was generated through partitioning based on the drainage area of reported flows up to the river tributaries [54]. Irrigation districts were modelled as one collective water user because water use information is generally available as a cumulative volume per region $[7,24,39]$. Kapchagay reservoir storage was based on elevation data from KazHydromet for the time frame of 2001-2016 and design data [41]. Currently, operation of the reservoir prioritizes water storage in spring, summer, and autumn to generate power during the winter months for heating $[6,8]$. An overview of more detailed operating policies is included in Appendix B.

Model calibration for the IBB model in RiverWare was carried out by simulating historical conditions, including historical inflows, diversions, and dam operations. Hydrologic inflows and pool elevations were used wherever possible to drive the model. Calibration parameters include evaporative losses, channel gains and losses and local inflows. Calibration adjustments were performed from January 2001-December 2008, followed by validation for the period from January 2009-December 2016. This period was chosen based on availability of pool elevation information of the Kapchagay reservoir and extends beyond the typical calibration/validation period of 3 to 5 years [49] to capture a wider range of hydrological variability.

Validation characteristics were calculated through NSE, percent bias (PBIAS) and RSR at each gauge location [49], performance of the model is considered good or very good at the gauge locations (Table 2; Appendix C). The performance of the model is acceptable, although limited data on Kapchagay dam and reservoir characteristics affect the calibration results for gauges below the dam ("Below Kapchagay") and reservoir pool elevation (See Appendix C for details), necessitating more detailed local data for (daily) planning use.

\section{Water Demand Scenarios}

Using six different agricultural water demand scenarios, we explored the impact of a range of uncertain upstream Chinese developments on downstream water security outcomes in Kazakhstan (See Table 3). As the ongoing rapid economic development in the Chinese Ili Valley has thus far contributed to a significant increase in irrigated area and water demand. Along with the area under irrigation, rice cropping in the Chinese Ili Valley is explicitly considered based on the high water demand compared to other crops and several references to plans for more rice production $[14,23,24]$. Despite the lack of 
a transboundary agreement, these scenarios inform decision-makers about the potential downstream impacts.

Table 2. Calibration and validation results for the Ili basin model in the RiverWare platform.

\begin{tabular}{|c|c|c|c|c|c|c|c|}
\hline \multirow[t]{2}{*}{ Gauge Location } & \multicolumn{3}{|c|}{$\begin{array}{c}\text { Calibration Period } \\
\text { January 2001-December } 2008\end{array}$} & \multicolumn{3}{|c|}{$\begin{array}{c}\text { Validation Period } \\
\text { January 2009-December } 2016\end{array}$} & \multirow[t]{2}{*}{$\begin{array}{c}\text { Evaluation } \\
\text { Based on [36] }\end{array}$} \\
\hline & NSE & PBIAS & RSR & NSE & PBIAS & RSR & \\
\hline "Yamadu" & 0.99 & $1 \%$ & 0.39 & 0.99 & $1 \%$ & 0.35 & Very good \\
\hline "Dobyn" & 0.99 & $1 \%$ & 0.39 & 0.99 & $1 \%$ & 0.35 & Very good \\
\hline “164 km above KapHES” & 0.80 & $7 \%$ & 0.47 & 0.84 & $5 \%$ & 0.42 & Very good \\
\hline [Below] "Kapchagay" & 0.60 & $6 \%$ & 0.52 & 0.78 & $8 \%$ & 0.45 & Good \\
\hline
\end{tabular}

Table 3. Upstream irrigation water demand scenarios.

\begin{tabular}{|c|c|c|}
\hline Scenario Name & Description & Simulated in Chinese Ili Valley \\
\hline AC 1 & $\begin{array}{l}\text { Baseline scenario with existing crop pattern and area } \\
\text { under irrigation, based on estimates from }[23,24]\end{array}$ & $7350 \mathrm{~km}^{2}$ irrigated land; $15 \%$ rice $\left(1105 \mathrm{~km}^{2}\right)$ \\
\hline $\mathrm{AC} 2$ & $\begin{array}{l}\text { Expansion: Current irrigated land use extent with } \\
\text { increase of wet rice cultivation to } 50 \% \text { of total }\end{array}$ & $7350 \mathrm{~km}^{2}$ irrigated land; $50 \%$ rice $\left(3675 \mathrm{~km}^{2}\right)$ \\
\hline AC3 & $\begin{array}{l}\text { Expansion: The maximal potential irrigable land } \\
\text { area with the same cropping pattern as AC1 }\end{array}$ & $12000 \mathrm{~km}^{2}$ irrigated land; $15 \%$ rice $\left(1800 \mathrm{~km}^{2}\right)$ \\
\hline $\mathrm{AC4}$ & $\begin{array}{c}\text { Expansion: The maximal potential irrigable land } \\
\text { area with increase of wet rice cultivation to } 50 \% \\
\text { of total }\end{array}$ & $12000 \mathrm{~km}^{2}$ irrigated land; $50 \%$ rice $\left(6000 \mathrm{~km}^{2}\right)$ \\
\hline AC5 & $\begin{array}{l}\text { Mitigation: Environmental Protection Plan } \\
\text { maximum water consumption [43] with the same } \\
\text { cropping pattern as AC1 }\end{array}$ & 7.12 BCM upstream water consumption per annum \\
\hline AC6 & $\begin{array}{l}\text { Mitigation: Water saving, based on irrigation } \\
\text { demands 1976/77 [24] }\end{array}$ & $5000 \mathrm{~km}^{2}$ irrigated land; Rice cultivation negligible \\
\hline
\end{tabular}

Following the approach by [45], we simulated one baseline scenario (AC1), three scenarios with agricultural expansion up to the maximal potential area under irrigation and an increase of rice cropping from $15 \%$ to $50 \%$ (scenarios AC2, 3, 4), and two mitigation scenarios based on the current governance framework (AC 5 and 6). Due to data restrictions, scenario development relied on remotely sensed historical data $[7,23,24,27]$. An irrigation water efficiency value of 0.6 was assumed, taking an average value from [55] (0.48) and [39] (0.7). In this study, we used the most recent estimate from [23] as the baseline for current irrigated area (scenario AC1), assuming a cropping pattern with 15\% rice [24].

Within the current governance framework, the Chinese Environmental Protection Plan and water saving strategies are the main options. The agricultural water use cap of 7.12 BCM by 2030 proposed by the EPP of the Ili Prefecture [43] in Scenario AC5, and an estimate of water use from 1976 [24] as a proxy for implementation of potential water saving technology or more water efficient crops (AC6). Combining the six water demand scenarios with the two sets of river conditions (representing the historical flow regime and climate change) resulted in 738 simulation runs.

\subsection{Performance Metrics}

One of the frequently used definitions of water security is "the availability of an acceptable quantity and quality of water for health, livelihoods, ecosystems and production, coupled with an acceptable level of water-related risks to people, environments and economies." [56]. In this definition, water security is framed as an inherently risk-based 
challenge, where both physical and governance properties of the water system influence performance $[57,58]$. This study focuses on quantitative reliability and robustness of flows to stressors as primary conditions for water security, exploring the ability of the water system to meet different sectoral needs under future supply and demand trends. Availability of locally defined environmental requirements and the importance of shortages and annual water quantity in the political discourse on the IBB in the transboundary context guided this choice [12-14,59].

Performance and vulnerability of the system is primarily evaluated using reliability as a key metric, along with flow duration characteristics, environmental shortage and robustness. These metrics are a selection of a wide range of water security evaluation criteria used in decision-scaling approaches [60]. Although in-depth assessment of environmental flow requirements is lacking in the IBB, several assessments suggest a minimum annual inflow to the Ili delta of 11 BCM to maintain the wetlands and Lake Balkhash $[9,24,61,62]$. Historically, flows below this value have occurred, and the shortage metric provides insight into intensity and frequency of low flows. Reliability allows for inter-comparison of different demand and hydrological scenarios, defined as the frequency of the system meeting environmental flow objectives [63]; we assumed an inflow to the delta of at least $11 \mathrm{BCM} /$ year as the environmental target with reliability outcomes expressed as a percentage of years in the modelled runs meeting this objective. In this study, a scenario is considered robust if reliability is equal to or greater than $90 \%$.

\section{Results}

The results show the sensitivity of the basin to the combination of stressors: (i) land use change and historical hydro-climatic variability, (ii) potential future climate change under current water demand, and (iii) the combination of land use development and future hydro-climatic changes for the period of 2020-2060.

\subsection{Tension between Upstream Demand and Downstream Water Shortages under Historical Hydro-Climatic Conditions}

If the hydro-climatic regime of the Ili for 2020-2060 remains unchanged compared to the past 50 years [44], and agriculture continues to expand in China, future water supplies will become increasingly strained. Current and all future simulated agricultural development scenarios result in a percentage of years in the simulated period with annual flows below the identified environmental requirement of 11 BCM (see Figure 5). Overall, downstream flows appear sensitive to increases in upstream water use under historical hydrological conditions. Results show that under current demands (scenario AC1), almost half of the years in the 80 runs resulted in annual flows of 9-11 BCM (see Figure 5). Under high-demand scenarios (AC2, 3, 4), downstream shortages become more frequent and more severe. Environmental requirements are the most pressured under scenario 4 , where for $70 \%$ of years in the 80 runs, annual flows would be below the pre-defined environmental target. The lowest recorded annual flow in the historical dataset is $7 \mathrm{BCM}$, yet under scenario 4 , flows would drop below 7 BCM for $20 \%$ of the simulated years. Particularly the expansion of rice in the Chinese Ili Valley would result in more years with flows below $7 \mathrm{BCM}$. This first set of results then raises questions on the suitability of rice and highlights the potential impact of upstream decision-making.

Two potential mitigation strategies, the Environmental Protection Plan (EPP) of the Chinese Authorities and rigorous water saving (scenarios AC5 and 6, see Figure 2) offer insight into the mitigation potential under the current governance framework. The EPP for the Ili Valley states an upper limit for water use in the Ili Valley from 2030 onwards (scenario AC5). This would result in a similar situation as the current demands (scenario AC1), although water shortages are slightly more intense for the same number of years below the reliability threshold, with a larger share of 2 to $4 \mathrm{BCM}$ shortages per year. This appears to be the effect of the slight increase in upstream water consumption provided for in the Environmental Plan compared to the current situation. The only scenario with distinctly better outcomes for reliability of flows to the delta and Lake Balkhash under historical 
hydro-climatic variability is scenario AC6, where upstream water use is reduced to 1976 (pre-development) levels. Such water use levels could be achieved by radically increasing water efficiency or reducing acreage under irrigation.

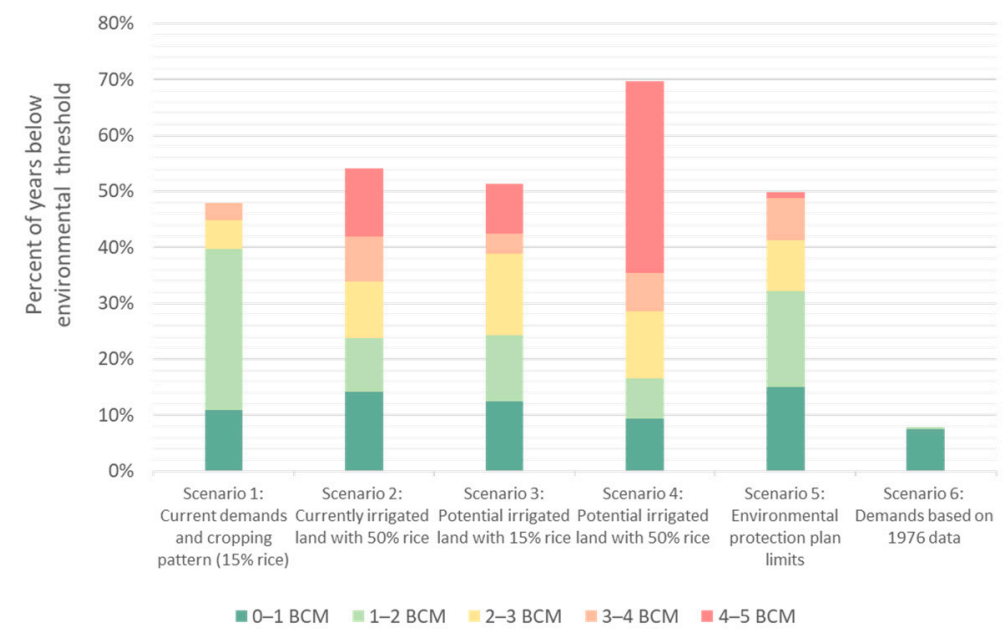

Figure 5. Basin response to the six scenarios representing varying agricultural water demand development (scenarios AC1-6). Response is explored through reliability of environmental flows and the intensity of shortages to the Ili delta. The literature suggests that $11 \mathrm{BCM}$ per year is critical.

\subsection{Basin Response to Precipitation Changes}

However, regardless of local decision making on water use, the Ili Basin is facing the potential impacts of global climate change. Flows are particularly sensitive to changes in precipitation (see Figure 6). As precipitation decreases, the total flows (area under the curve) decrease and very low monthly flows (below $100 \mathrm{cms}$ ) become more likely. However, if precipitation increases, the probability of very low flows is diminished. One peculiar observation is the disappearance of flows in the $-50 \%$ scenario around the $50 \%$ exceedance probability mark, indicating the non-viability of surface hydrological conditions under such circumstances. This complete depletion may be explained by the inflexibly modelled demands. Overall, the different precipitation scenarios demonstrate the sensitivity of the system to changes in upstream precipitation under stable temperature conditions with the current water demands: less precipitation generally results in lower total flows.

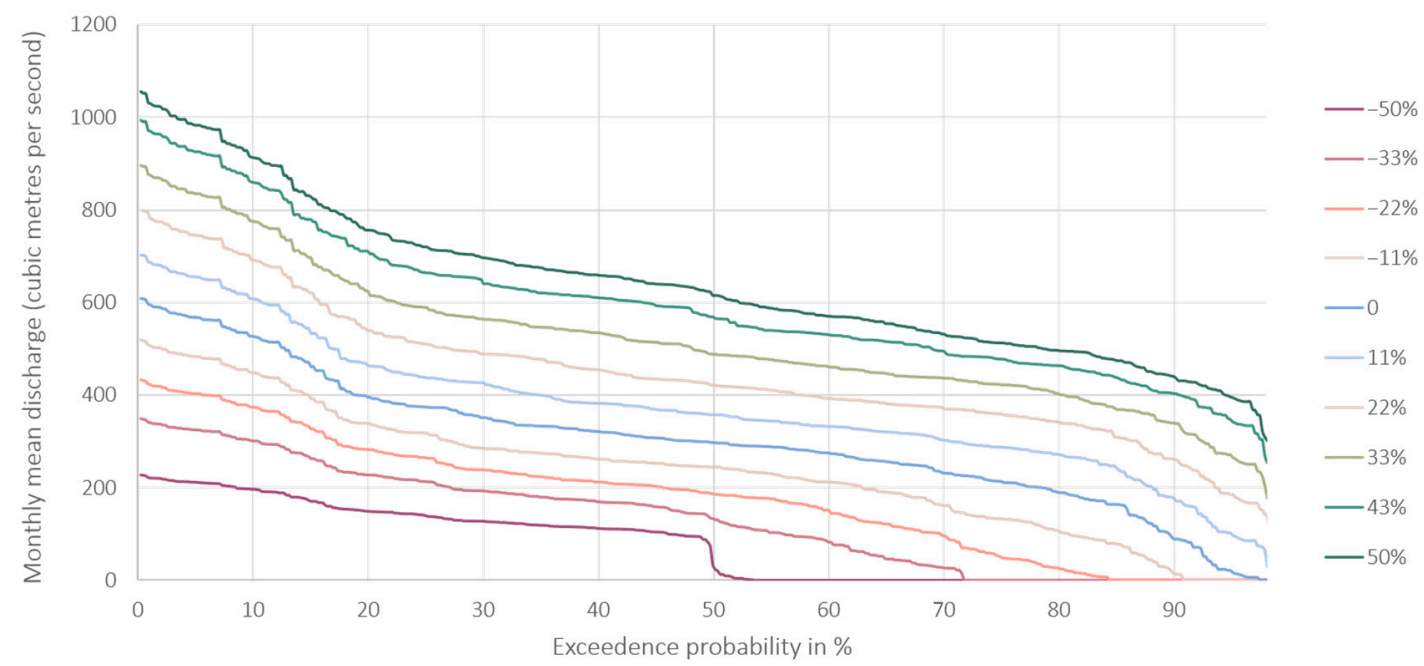

Figure 6. Flow duration curves of the Ili river for different precipitation scenarios ( $-50 \%$ to $+50 \%)$ under stable temperature and current demands in the upper Ili Valley. 


\subsection{Impacts of Climate Change and Demand Development on Flow Reliability Downstream} 4.3.1. Reliability under Demand Change under Uncertain Climate Futures

Assessing water security under both water demand and climatic changes compared to the baseline period indicates that the basin is highly sensitive to shifts in these conditions (see Figure 7). The combination of demand change with shifts in the climatic regime yield extreme outcomes for environmental flow reliability, with a small range of intermediate reliability. Our definition of environmental flow reliability is the frequency that $11 \mathrm{BCM}$ of water can reach the delta each year; the scenario runs where reliability is $0 \%$ would mean that flows drop below 11 BCM for all modelled years. While assessment of future water security under historical variability (Section 3.1) also suggests reliability is sensitive to increases in upstream demands, precipitation and temperature appear to be important mediating factors. Reductions in precipitation and temperature respectively amplify pressure on environmental water security downstream. To illustrate this, Figure 7 shows very low reliability values for current demands (Demand scenario AC1) under the historical climatic regime (P5T2) and any decrease in precipitation (P1-4). This directly relates to the sensitivity of total flows to precipitation and shows limited buffer capacity of the system to ensure environmental flows. Additionally, the existing high demands at the baseline, frequent low-flow conditions under the natural regime, and the modelled inflexibility of demand may contribute to the nearly binary outcomes presented in Figure 7.
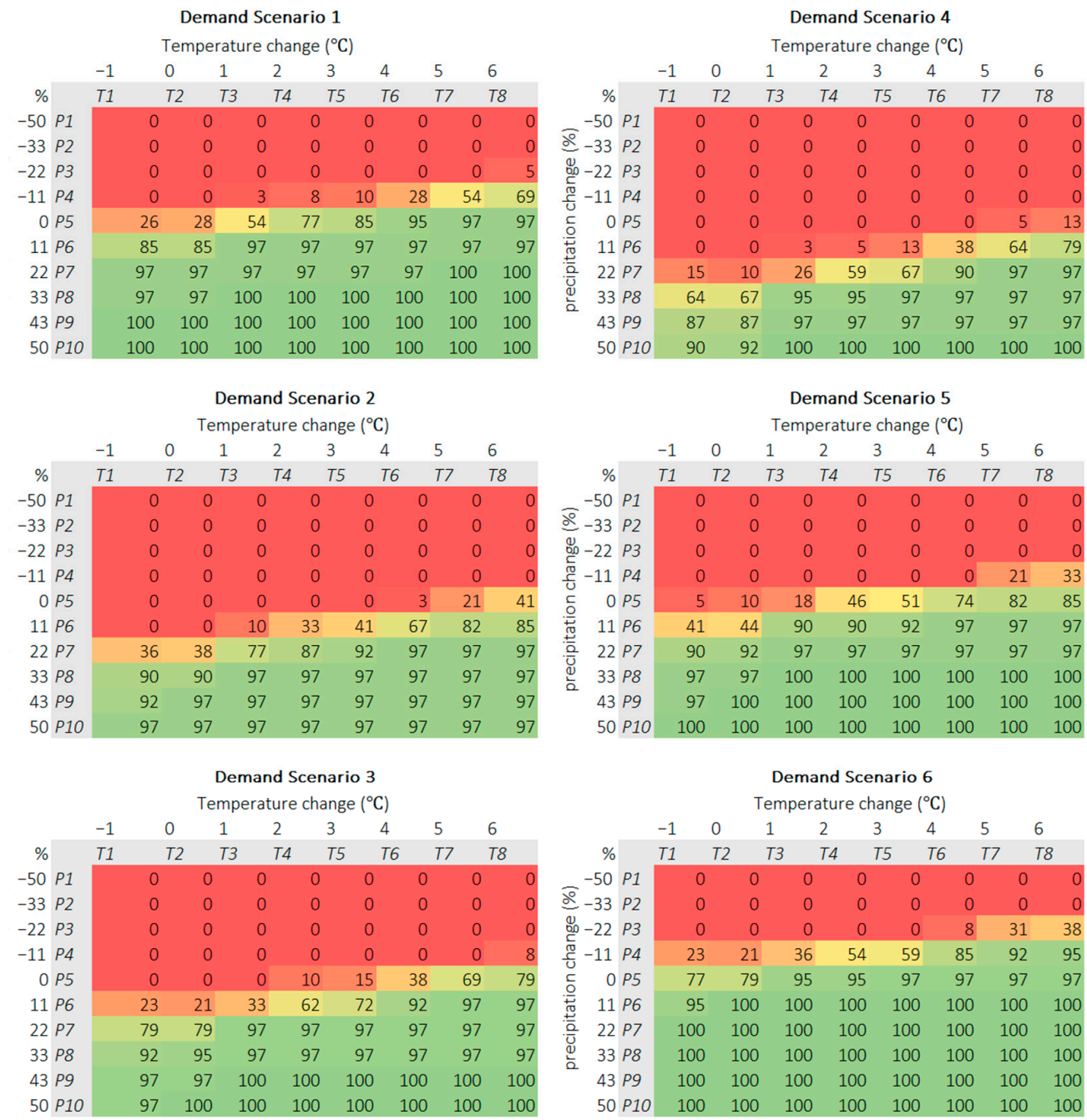

Figure 7. Surface response tables of reliability of flows to the lower Ili, expressed as the percentage $(\%)$ of years per model run meeting the environmental requirement of $11 \mathrm{BCM}$ per year, with the green to red gradient indicating high to low reliability. 
In contrast, higher temperatures and precipitation in the upper catchment cause a reliability improvement downstream, and partly counter-balance pressure from increasing upstream demands. While higher temperatures cause higher evapotranspiration, it also increases runoff through more meltwater and rainfall rather than snowfall in the mountainous upper Ili. For the potential agricultural expansion scenarios (AC2, 3, 4), environmental flows can only be met with an increase in precipitation and temperature. A shift from the current situation to more rice cropping (scenario AC1 to scenario AC2) would require about $25 \%$ more precipitation and $3{ }^{\circ} \mathrm{C}$ degrees higher annual temperatures to achieve a reliability over at least $50 \%$ (see Figure 7). Demand scenario 4 is the most extreme water-use scenario tested, and environmental requirements in this scenario would only be satisfied when accompanied with $+33 \%$ increase in precipitation or $+4{ }^{\circ} \mathrm{C}$ degrees warming by 2060 . These findings indicate that for any growth scenario, currently available water is insufficient to satisfy all upstream and downstream demands simultaneously, and upstream demand increases will negatively affect downstream water availability. Conversely, more agricultural development without negative downstream environmental impacts may be feasible under change scenarios with higher temperatures and more precipitation, although this is likely to be complicated by climatic knock-on effects not directly considered in this study.

\subsubsection{Managing Flows under Climate Change}

The currently available mitigation strategies have limited mitigation potential under climate change; although reliability outcomes of both the EPP and water saving scenario (AC5 and 6) are higher compared to unrestricted expansion scenarios (AC2-4), these strategies only work for a subset of the potential hydro-climatic futures (see Figure 7). For the $\mathrm{EPP}$, a very high increase in temperature $\left(3^{\circ} \mathrm{C}\right.$ or higher by 2060$)$ would still be required to maintain environmental flows for at least $75 \%$ of the time at stable precipitation conditions. Environmental requirements would not be met in all years under even the smallest decrease in precipitation, which does raise concerns about the future sustainability of this environmental protection plan. Alternatively, in the potential situation where water demand is decreased to the same level as 1976 (scenario AC6), either through decreasing cropping area, different cropping patterns or improvement of irrigation efficiency, a large improvement of reliability of environmental flows is observed. This is the only land use scenario with a buffer to decreased precipitation. Environmental needs could still be met in more than half of the years under a decrease in precipitation of $11 \%$ if temperatures increase by $2{ }^{\circ} \mathrm{C}$. Outcomes analysing irrigation water and hydropower water supply reliability of the system can be found in Supplementary Materials (Figures S1-S4).

\subsubsection{Climatic Robustness of Demand Scenarios}

To contextualize the reliability of environmental flows and the range of climate projections, we explored basin outcomes for the CMIP5 GCMs. Under RCP2.6, 4.5, 6.0 and 8.5 , GCM ensembles project precipitation increases of $7-9 \%$ by 2060 , and temperature projections range from $1.64{ }^{\circ} \mathrm{C}$ mean warming to $4.04{ }^{\circ} \mathrm{C}$. However, such averages mask the variability of different GCMs within each ensemble, which often yield contrasting outcomes for the same water demand scenario (see Figure 8).

In the Ili-Balkhash basin, scenario AC6 would result in the best environmental outcomes downstream, with high reliability (90\% or higher) for $84 \%$ of the assessed GCM models, followed by the current demands with 78\% of the GCMs (scenario AC1). However, for the scenarios with similar or higher water demands (AC 2, 3, and 4), only 11\%, 38\% and $3 \%$ respectively of the GCMs result in high environmental reliability (>90\%). Furthermore, for these high demand scenarios (scenarios AC2-4), 59\%, 30\% and 69\% respectively of the GCMs yield low reliability (below 50\%). The Environmental Protection Plan (scenario AC5), yields high reliability for $41 \%$ of the GCMs, while $17 \%$ of the GCMs result in low reliability (below 50\%). This indicates that the EPP is more robust to climate change in comparison to 
the demand growth scenarios (AC 2, 3 and 4), yet performs worse compared to the current demands (scenario AC1) and the extensive water saving scenario (scenario AC6).

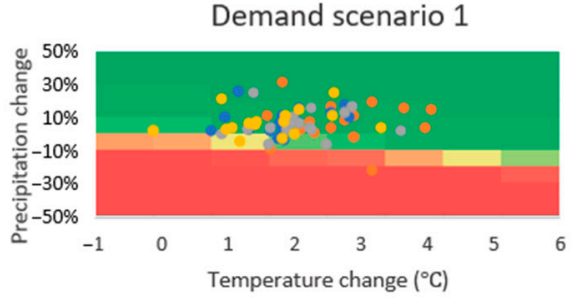

Demand scenario 2

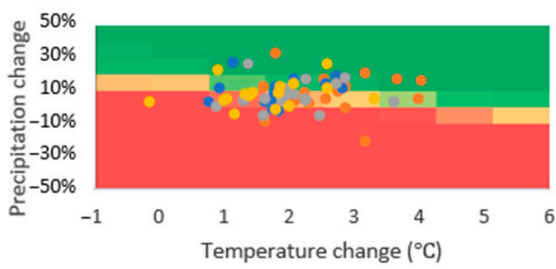

Demand scenario 3

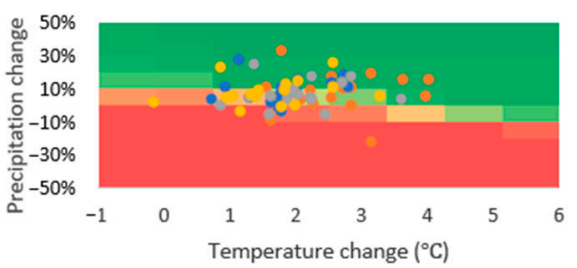

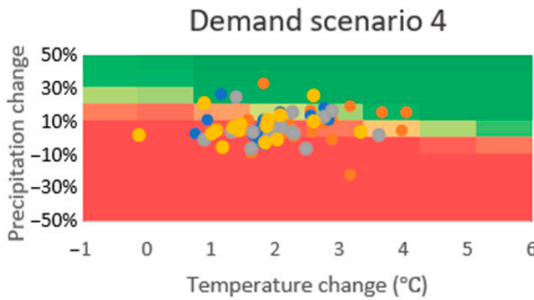

- RCP8.5

- RCP6

- RCP4.5

- RCP2.6

Demand scenario 5

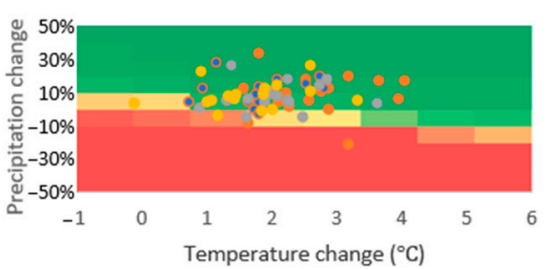

Reliability

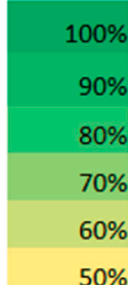

Demand scenario 6

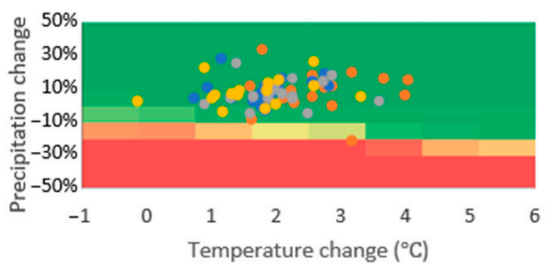

Figure 8. GCM projections for RCP2.6, RCP4.5, RCP6 and RCP8.5 and reliability of environmental flows to the Ili delta under six different upstream water demand scenarios.

Nonetheless, even for the most robust scenario (scenario AC6), 17\% of the assessed GCMs project a future with reliability below the $90 \%$ mark. As such, even if the most robust demands scenarios can be achieved, decision-makers should also plan for less beneficial climatic futures that may negatively affect water security downstream. This indicates that improving the ability of the basin to cope with both extreme and moderate future climate change and demand shifts simultaneously, requires attention to water consumption upstream and demands downstream, and should plan for potentially widely variable future water availability. The main findings are summarized in Table 4.

Table 4. Summary of main findings.

\section{Main Findings}

Historically, environmental water shortages were already frequently occurring in the IBB, and may intensify and become more frequent if upstream water use increases.

Future reliability of environmental water supply to the Ili Delta is negatively affected by precipitation reductions, temperature reductions and upstream water demand increases.

Current available mitigation strategies (Environmental Protection Plan of the Ili Prefecture and a general water saving agenda) may enhance downstream reliability under slight to moderate climatic change, yet are unable to mitigate larger shifts in demand or hydro-climate.

The IBB system is currently under pressure and vulnerable to demand and climatic changes, and potential increased demands would drastically reduce basin robustness to climate change.

There is scope for improvement in sustainable expansion of agriculture upstream if parties cooperate and coordinate water use. 


\section{Discussion}

Based on the modelling results under the historical flow regime, the basin is prone to droughts and low-flow conditions even under moderate water use scenarios. This is confirmed by the observed gradual degradation of Ili Delta vegetation in the last 20 years [23]. Interestingly, the water level of Lake Balkhash has remained stable over the past decades [64-66], except for a rapid drop of the lake's water levels between 1970 and 1990 to the lowest recorded in 1987 as a result of reduced water availability during the filling of the Kapchagay reservoir $[5,61,62,66]$. This suggests that except for a sudden reduction in flows, the ecosystem has the capacity to absorb natural high and low flow shocks. An explanation currently under investigation is the buffering capacity of the extensive river delta water surfaces and groundwater dynamics $\left(8000 \mathrm{~km}^{2}\right)$; remote sensing studies indicate that the surface area of small ponds and lakes in the delta fluctuate according to Ili flow conditions $[9,64]$.

Looking ahead, changes in rainfall and temperature regimes in the basin as a result of global climate change may force a shift in the hydrology of the Ili. Results in this study indicate that between moderate decreases and increases $(-11 \%$ to $+11 \%)$ in precipitation may cause a particularly large difference in quantitative water security outcomes downstream. Marsuryama and Kezer [67] and Propastin [15] also concluded that the Ili River is predominantly sensitive to precipitation changes, based on historical data. However, there is disagreement on precipitation projections in the Ili-Balkhash basin. Projections from the assessed GCMs for RCP4.5 range between a -5 and $+10 \%$ monthly precipitation change by the 2060s. The wide range of precipitation scenarios chosen in this study, based on the scenario-neutral methodology [32], proved useful to explore these sensitivities. As the small rainfall differences may yield variable security outcomes, future studies could explore more precipitation scenarios in a narrower range and smaller steps.

On the other hand, the positive impact of increasing temperature upstream on runoff and water security downstream should be interpreted carefully. Temperature changes primarily affect glacial and snowmelt flows in the basin $[27,68,69]$, and the Ili depends on glacier- and snow-melt for $15 \%$ of its flows per year, and up to $25 \%$ of flows during the growing season [27]. In the $\mathrm{ABCD}(\mathrm{E})$ model, the snow- and ice-melt parameter was assumed to remain stable in the future, although this may change under climatic shifts too. There was too little data to establish such future trends at this moment. Nonetheless, in agreement with our results, several authors predict higher meltwater flows for the next decades as a result of higher temperatures $[28,68,70]$. However, the glacial melt component of river flow may disappear after the "peak meltwater date", and there is ongoing debate about the duration of high meltwater yields and water supply after the peak [71-73]. A global study estimates this peak date to lie between 2030 and 2050 in the IBB [71]. Scenario analysis by [72] indicated glaciers may completely disappear by the 2090s in the Tian Shan under future warming of $+6^{\circ} \mathrm{C}$. Therefore, the timescale is important, and the study timeframe (2020-2060) may not capture the post-peak dynamics. The hydrological model (ABCDE) does not address temporal dynamics of glacial melt specifically [47] and there is further scope to explore impacts on evaporative losses as well. This study therefore offers insights into the dynamics of this high meltwater yield period but does not predict nor address water availability for far-progressed glacial degradation.

Above all, the results underline the potential influence of changes in upstream water use on downstream water availability for different water users, intensifying existing tradeoffs. However, it remains difficult to discuss the likelihood of different future development scenarios due to large gaps in data as a result of the political situation in Xinjiang, the rapid change under the BRI policy agenda and agricultural modernisation throughout NorthWest China. China's hegemony, reinforced by the BRI, leads to rapid change in cultivation practices and water regimes. The limited information available indicates that development plans for the next decades designate the Chinese Ili Prefecture as key grain-production area, with less attention for rice [11]. Perhaps this makes demand scenarios 2 and 4 (both 50\% rice cropping) less probable and more moderately increasing demands (scenario AC3 with $15 \%$ rice cropping) more likely. Agricultural development remains a priority area in the 
current Five Year Plan of the Chinese government, and land use change studies indicate continued conversion of scrub and grassland into irrigated agricultural fields [23].

While expansion of agriculture in the upper Ili is likely, Kazakh development plans also warrant further exploration. Results of this modelling study suggest that reduction of downstream water demands may alleviate potential environmental water stress, although this is highly dependent on both the extent of upstream water use and climate trajectories. Recently researchers have called for re-examination of the water footprint of agricultural activity in the south of the Kazakh Ili basin, where intensive irrigated agriculture takes water from the small mountain tributaries that feed the lower Ili and Kapchagay reservoir [31]. Although these tributaries are thought to contribute only a minor component of flows [5,61], there is scope for further inclusion of these activities in assessments. While this study uses the modelling tools to explore the current governance status-quo, the RiverWare platform can be used to further explore different operating and allocation policies in the basin, focusing more on the social component and downstream agency within the water security concept. In addition, while this study limited its scope to the Ili, future research should explore dynamics in the whole Balkhash basin to include Kazakh agricultural and industrial water use plans as well. However, such specific analyses and trans boundary joint decision-making would require hydrological, operational and governance data from all involved parties. This currently remains the major challenge in the Ili-Balkhash Basin.

Despite the inter-dependence between sectors upstream and downstream in the IBB through their shared waters, it is unlikely that the political landscape will change drastically in the near future. Combined with the deep uncertainty about climatic trends, this underpins the need for further use of decision-making under uncertainty (DMDU) tools. While the study serves as a first step towards assessment of system performance and robustness, there is scope for further work. There are other criteria for vulnerability that may provide valuable insights, such as resilience (adaptability, persistence, transformability), and other locally defined categories [60]. Furthermore, this study focused on the CMIP5 GCMs, while Regional Climate Models (RCMs) or other models may enrich the analysis. Additionally, the results of this study may be refined by using more advanced thresholds for the evaluation metrics, as shortage and reliability in downstream areas: criteria for environmental flows, energy production and irrigation demands were based on limited local documentation. Nonetheless, the results offer insights for regional decision makers and researchers on what might be the consequences of changes in the IBB, opening up new avenues of analysis and planning.

Despite the uncertainties that complicate environmental assessments, investments and decisions are already urgently required, as demands for food, energy and water continue to grow and the impacts of global climate change start to manifest in the basin. Results demonstrate the sensitivity of the quantitative, reliability component of water security to demand and climatic stressors. To advance understanding of water security for Lake Balkhash and to mitigate growing pressures on the system, several knowledge gaps need to be addressed. Studies should particularly focus on water quality, groundwater dynamics and environmental requirements to maintain the delta-three important components contributing to water security that were not further explored in this study. The Ili model developed on the RiverWare platform allows integration of any new data and policies to explore impacts of management strategies, and is therefore a simple model that may potentially support transboundary discussions, researchers and local decision-makers [74].

The main finding relevant for near-term water management decisions is that different water demands and precipitation scenarios give widely different water availability outcomes, with low robustness of the assessed scenarios under the GCM projections. This calls for robustness as a key objective of any new and existing projects in the basin, planning for both increases and decreases in precipitation and upstream water use. Furthermore, results demand reconsideration of priorities in the basin, as mounting pressures also cause deeper trade-offs between sectors. In the lower Ili, such rethinking could consider drought- 
planning in dam operation of the Kapchagay reservoir and consideration of the high evaporation from the reservoir surface. Nonetheless, the competition for water between sectors under the current governance and operation remains a "wicked problem" [14], prevalent in many basins in Central Asia $[3,17,30]$. This research demonstrated the benefit of the bottom-up approach combined with the RiverWare modelling platform under data constraints. Exploring water user tensions and potential synergies, while integrating social and climatology uncertainty may prove useful for the many other transboundary basins in Central Asia under (perceived) stress, for example, the Irtysh (shared between China and Kazakhstan) and rivers in the Aral Sea basin.

This study primarily examines what will happen if China closes the tap and global climate change progresses throughout the 21st century. The future of the IBB is uncertain, as water demands are likely to increase to provide food and power to the burgeoning populations in the region. This study underlines the impacts of upstream development and (mis)management of downstream demands on water security in the whole basin. Brown [75] observes that we live in a time where common optimal objectives are hard to formulate, and the new objective is to find a range of politically feasible solutions. Moving away from sensitivity analysis, the next step is to explore the locally feasible options that consider the political landscape in the basin, which is changing rapidly under the BRI. The political tension between the potential gains to be made from further development in other sectors may obscure the agenda for environmental preservation, yet this study emphasises the potential consequences of inaction in this wicked problem. Above all, this study demonstrates the need for transformation of the transboundary governance, to allow for more hands on the tap and a rethinking of local governance in the Ili-Balkhash basin.

Supplementary Materials: The following are available online at https://www.mdpi.com/2073 $-4441 / 13 / 5 / 615 / s 1$, Figure S1: Intensity of irrigation shortages in the Chinese Ili Valley for the different future demand scenarios; Figure S2: Irrigation shortage in the Kazakh lower Ili region under the 80 future climate change scenarios and 6 upstream demand change scenarios; Figure S3: Absolute irrigation shortage per month in the lower Ili under upstream demand scenario AC1, with the shortages per month added up to annual shortage; Figure S4: Surface map of the sustainable water futures for the water-energy-food related sectors downstream. The number of risk thresholds crossed (0-3) is used as a proxy for overall water security risk in the lower basin under precipitation and temperature change. Criteria for a sustainable water future per sector are: annual flows into the delta of $11 \mathrm{BCM}$ in more than $51 \%$ of modelled years (based on Section 3.1), annual energy production greater than the mean value of recorded production (1000 MHW) and downstream irrigation shortages below the 80th percentile.

Author Contributions: T.d.B. developed and executed the research protocol under supervision of T.S., K.W., and H.P. T.d.B. made the model in RiverWare with support from K.W. H.P. assisted with the climate aspects of the project, and T.S. provided grounding in regional scholarship. T.d.B. developed the manuscript with support of K.W., H.P., and T.S. All authors have read and agreed to the published version of the manuscript.

Funding: None to declare.

Institutional Review Board Statement: Not applicable.

Informed Consent Statement: Not applicable.

Data Availability Statement: The data and models that support the findings of this study are available from the corresponding author, T.d.B., upon reasonable request.

Acknowledgments: The authors acknowledge the support from Thevs (CGIAR Central Asia and Greifswald University), Nurtazin and Salmurzauli (Al Farabi Kazakh National University) and their research team in accessing hydrological data and providing valuable insights into water management challenges of the Ili River.

Conflicts of Interest: The authors declare no conflict of interest. 


\section{Appendix A. Modelled Characteristics of Kapchagay Reservoir}

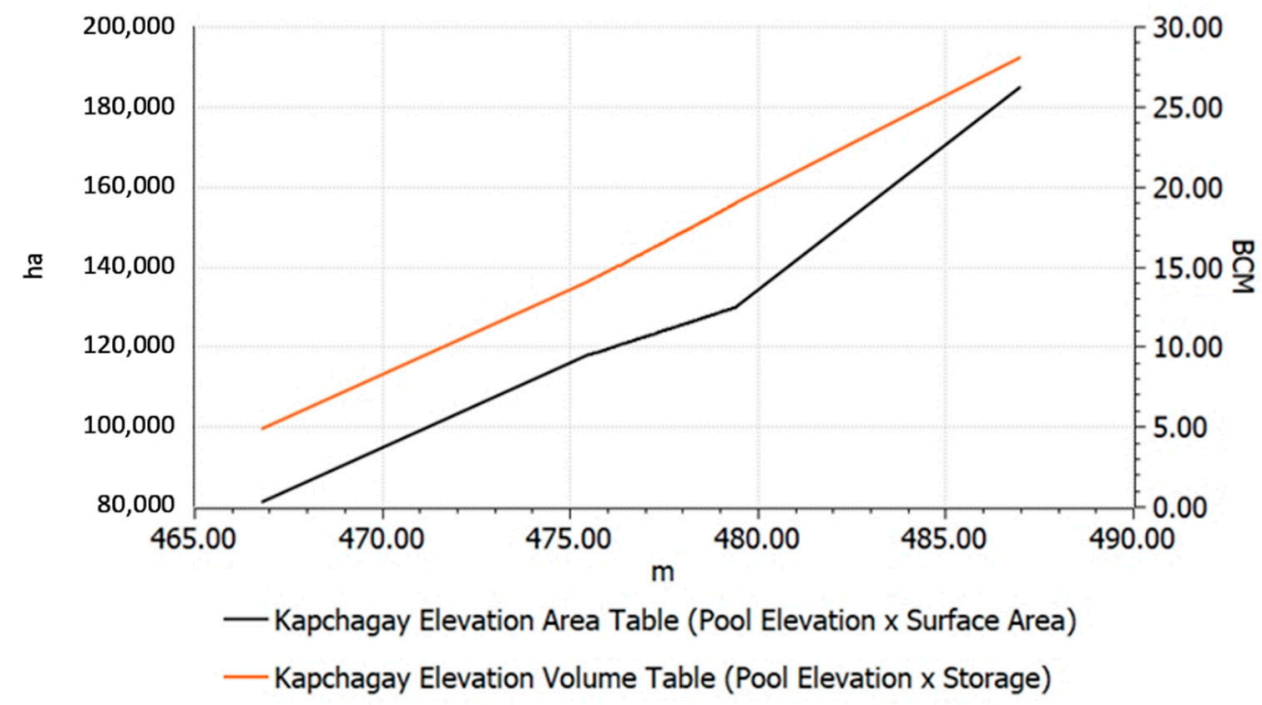

Figure A1. Elevation-Volume-Area data for the Kapchagay reservoir.

\section{Appendix B. Operation of Kapchagay Reservoir}

Table A1. Modelled characteristics of the Kapchagay dam.

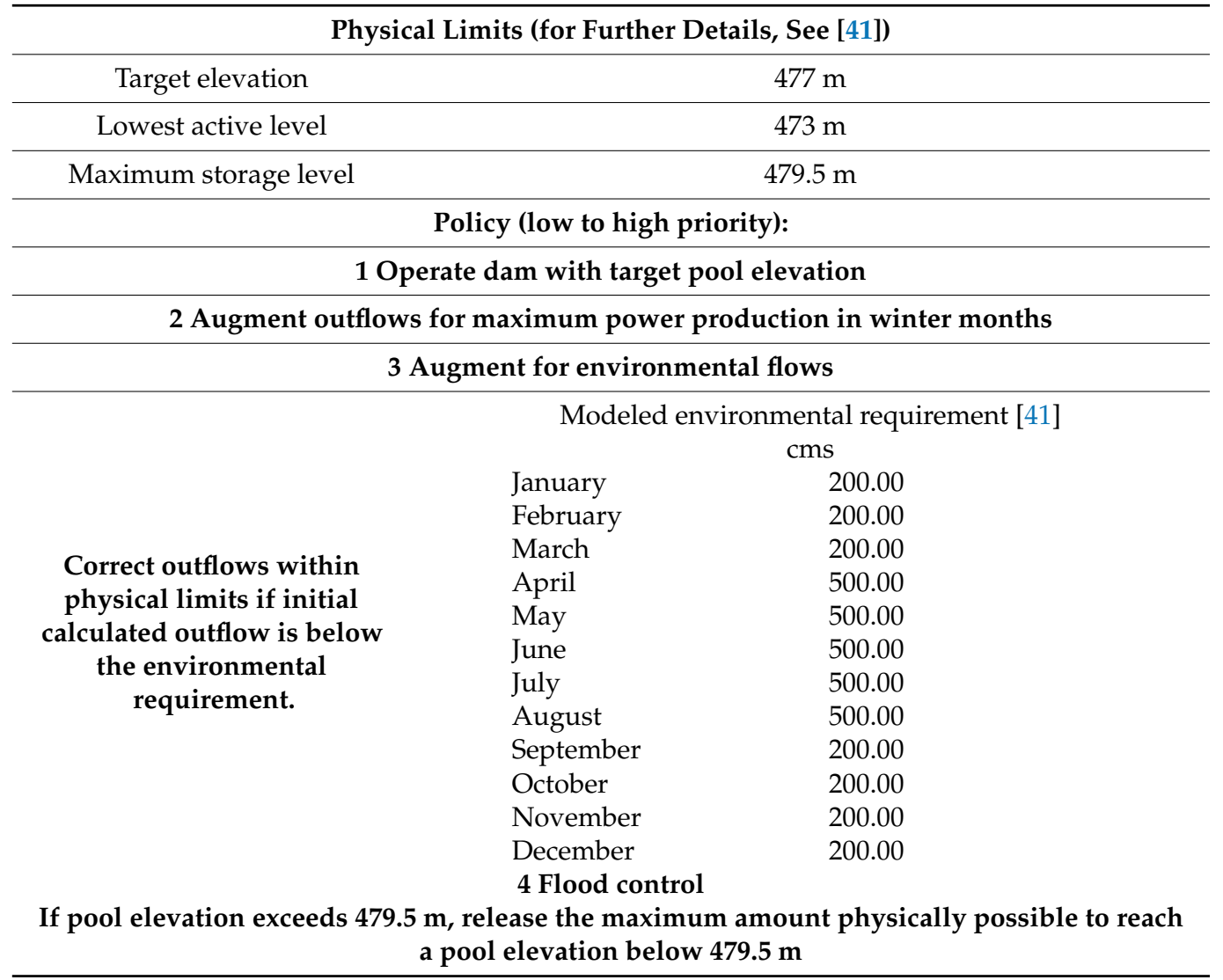


Table A2. CMIP5 GCMs used in assessment.

\begin{tabular}{cr}
\hline bcc_csm1_1 & Beijing Climate Center Climate System Model \\
\hline bcc_csm1_1_m & Ceijing Climate Center Climate System Model version 1.1 Moderate Resolution \\
\hline ccsm4 & Community Earth System Model (CESM) \\
\hline cesm1_cam5 & Commonwealth Scientific and Industrial Research Organisation MK3.6 Model \\
\hline csiro_mk3_6_0 & First Institute of Oceanography Earth System Model \\
\hline fio_esm & Geophysical Fluid Dynamics Laboratory Climate Model Version 3 \\
\hline gfdl_cm3 & Geophysical Fluid Dynamics Laboratory Earth System Model Version 2 \\
\hline gfdl_esm2m & NASA Goddard Institute for Space Studies E2-H Model \\
\hline giss_e2_h & NASA Goddard Institute for Space Studies E2-R Model \\
\hline giss_e2_r & Institut Pierre-Simon Laplace (IPSL) IPSL-CM5A-MR \\
\hline ips1_cm5a_mr & Japan Agency for Marine-Earth Science and Technology (MIROC) Earth System Model \\
\hline miroc_esm & Japan Agency for Marine-Earth Science and Technology (MIROC) Earth System Model Chemistry \\
\hline miroc_esm_chem & Model for Interdisciplinary Research On Climate Version 5 \\
\hline miroc5 & Meteorological Research Institute Coupled Global Circulation Model Version 3 \\
\hline mri_cgcm3 & The Norwegian Earth System Model
\end{tabular}

Table A3. Hydrological data completeness.

\begin{tabular}{ccc}
\hline Station Name & Time Period Available & Missing Data \\
\hline Dobyn & $2001-2016$ & 2002 \\
\hline 164 km above Kapchagay reservoir & $1973-2016$ & $1984,1989,1994,2002,2003$ \\
\hline$[$ Below] Kapchagay & $1950-2016$ & $1955,1961,1964,1965,1989,1994,2008,2009$ \\
\hline Ushurzarma & $1967-1999$ & $1989,1994,1995,1997,1998$ \\
\hline Zhideli & $1967-2016$ & $1994,1989,1996-2002,2006,2009$
\end{tabular}

\section{Appendix C. Model Performance Overview}

\section{Calibration and validation results for station "164KM"}

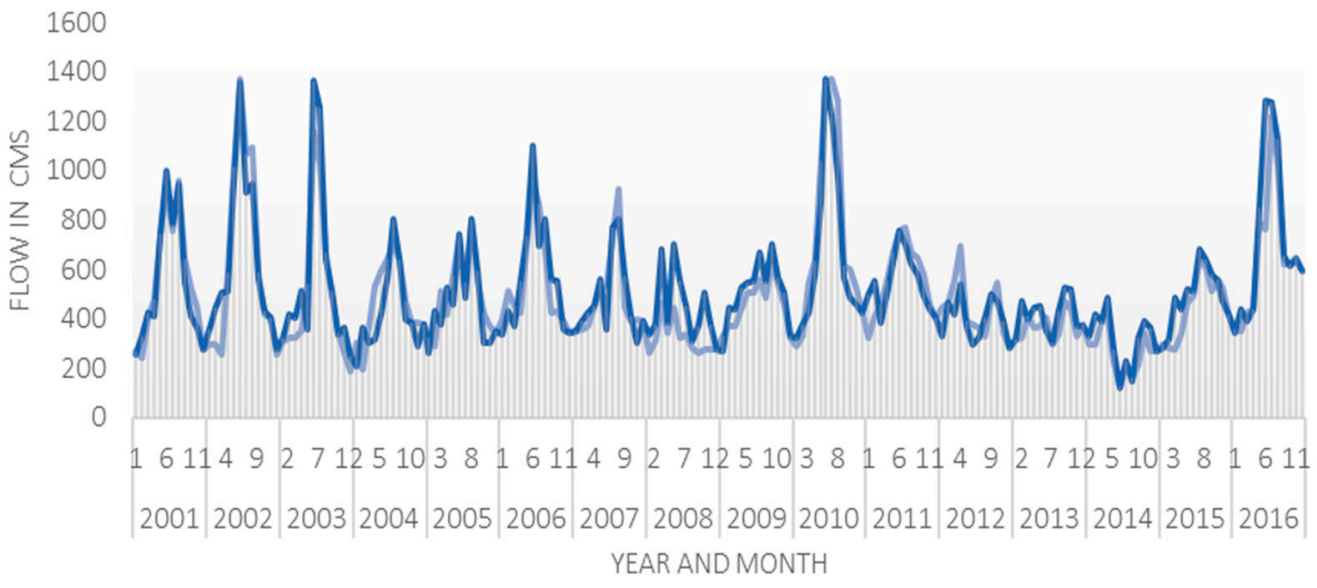

Gauged $164 \mathrm{~km}$ station Modelled $164 \mathrm{~km}$

Figure A2. Calibration and validation results for gauge station "164 km above KapHES". 


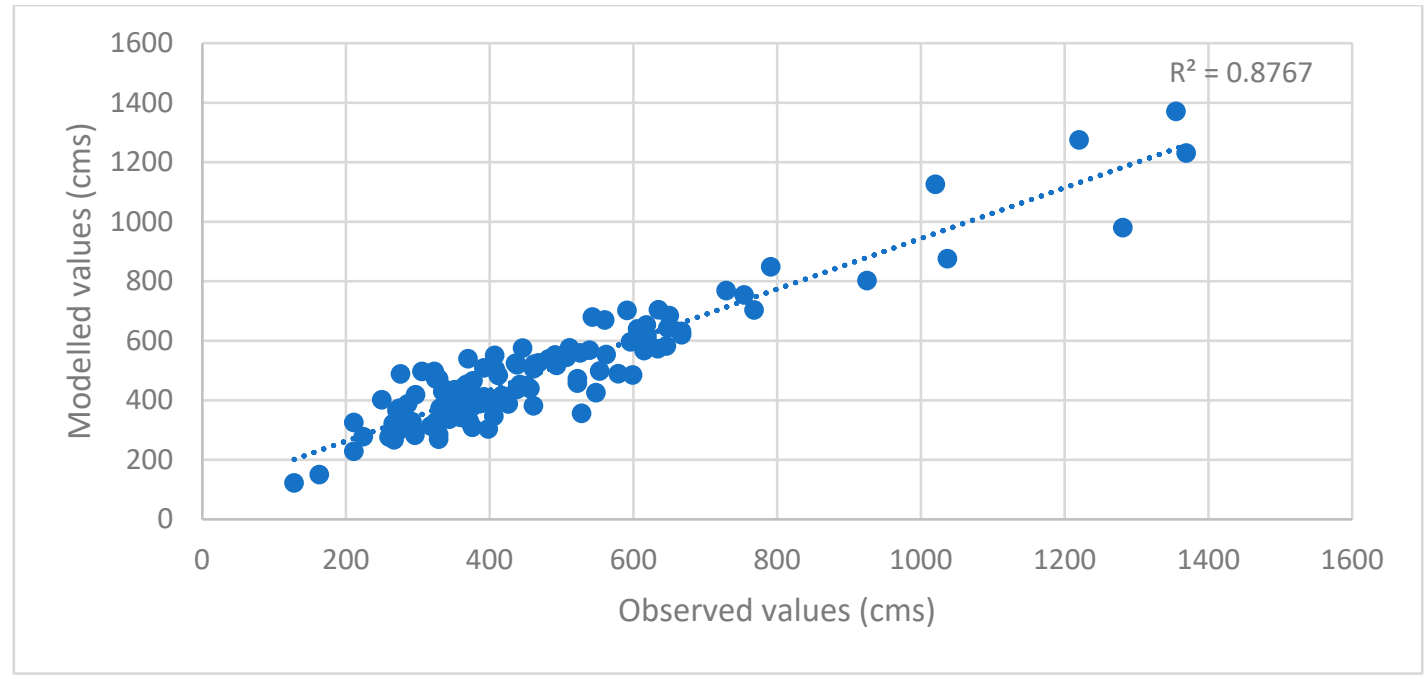

Figure A3. Correlation graph for gauge station "164 km above KapHES" with the R2 value.

Calibration and validation results for station "Kapchagay"

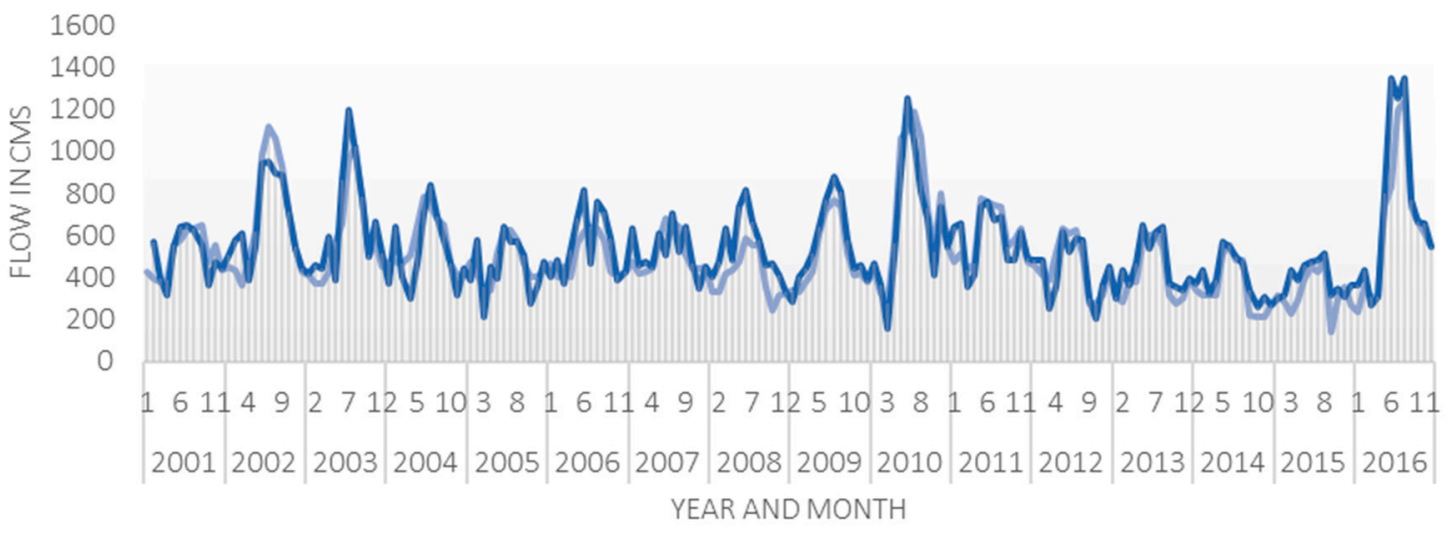

Gauged Kapchagay station $\quad$ Modelled Kapchagay station

Figure A4. Calibration and validation results for station "Kapchagay".

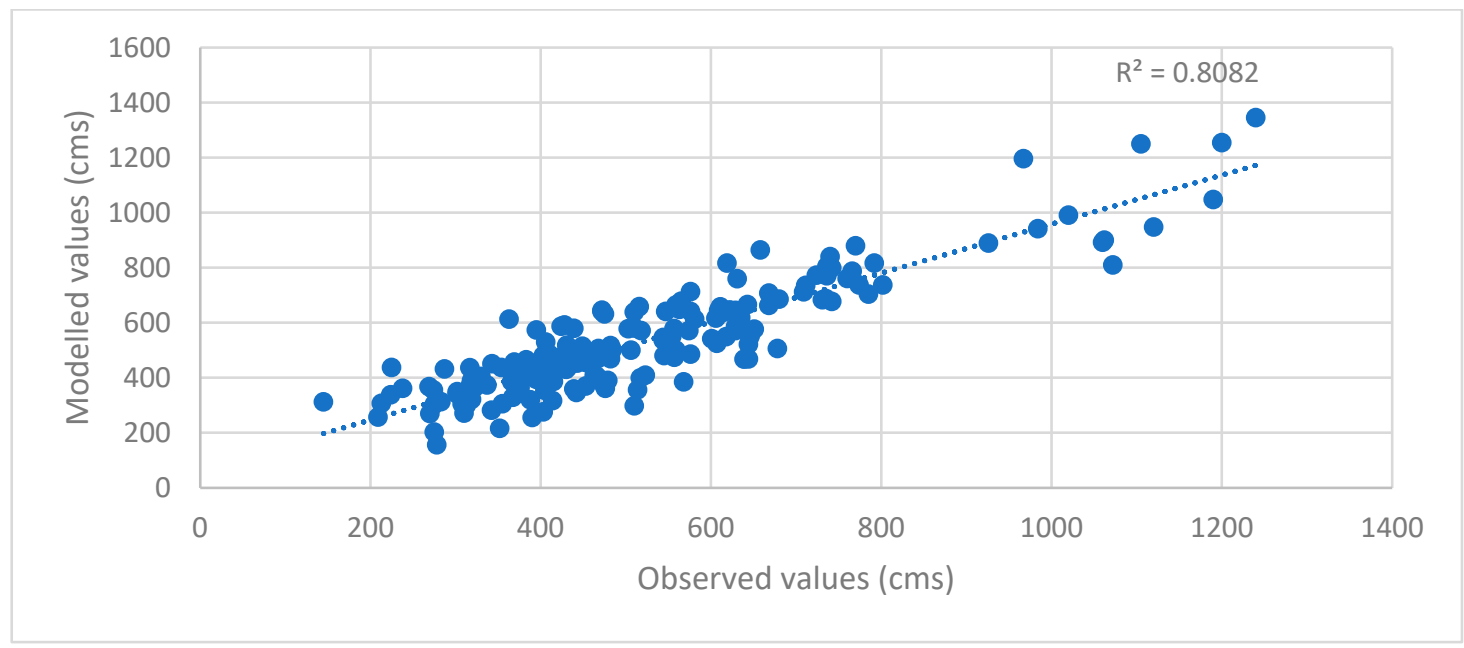

Figure A5. Correlation graph for gauge station "[Below] Kapchagay" with the $\mathrm{R}^{2}$ value. 


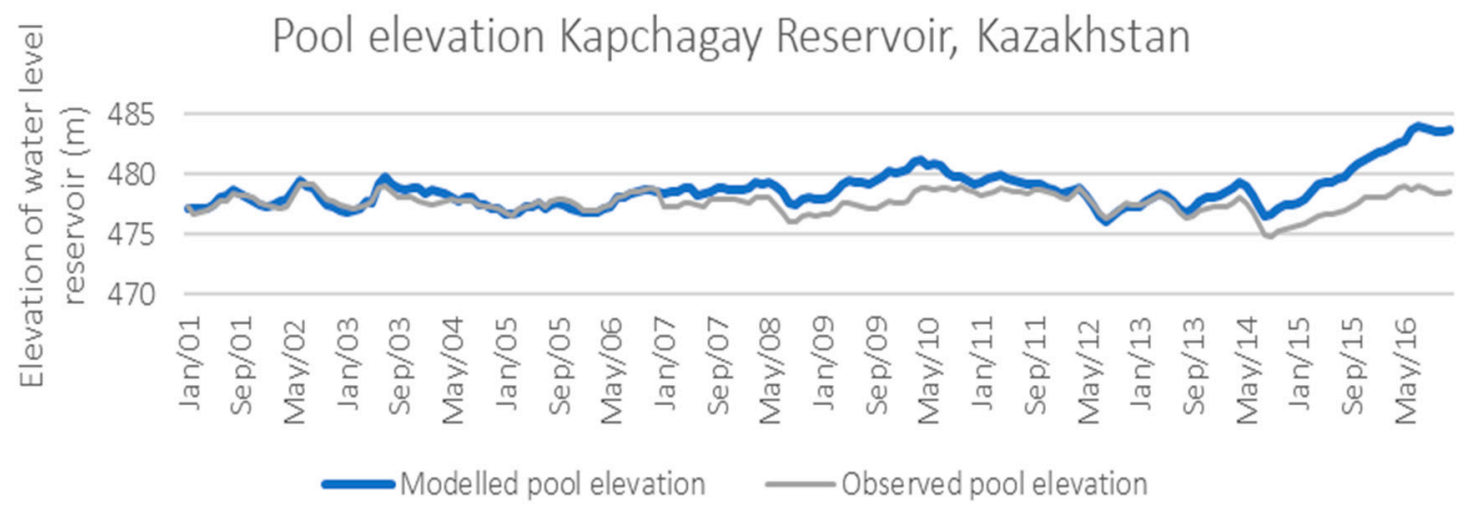

Figure A6. Pool elevation model predictions for Kapchagay reservoir.

Unfortunately, the pool elevation performance of the Kapchagay reservoir was less accurate (see Figure A6). Modelled pool elevations exhibit a similar pattern to observed values yet diverge from winter 2006 onwards with an additional spike in summer of 2008. Possible structural explanations are acceleration of sedimentation of the 50-yearold reservoir in recent years due to increased flows and unreported alterations to the dam, as was the case after a remodeling effort in 1994. The divergence in winter 2007 may be the result of measurement errors due to freezing of the river and reservoir from November to April. Ice jams, ice sheets and damage to gauges are reported frequently in Kazhydromet reports. The years 2008 and 2009 lacked data on gauged outflows of the reservoir, which may explain the failure to capture the drawdown in summer of 2008. Another drawdown occurred in winter and spring of 2014, an exceptionally warm and dry year where evaporation losses may have been higher than normal and tributary inflows much lower. The pool elevation performance will not affect the assessment of future flows directly due to the use of rule-based simulation in the analysis, although more work on Kapchagay reservoir is required to use the model for planning purposes.

\section{References}

1. Wang, J.; Song, C.; Reager, J.T.; Yao, F.; Famiglietti, J.S.; Sheng, Y.; MacDonald, G.M.; Brun, F.; Schmied, H.M.; Marston, R.A.; et al. Recent Global Decline in Endorheic Basin Water Storages. Nat. Geosci. 2018, 11, 926-932. [CrossRef]

2. Hijioka, Y.; Lin, E.; Pereira, J.J.; Corlett, R.T.; Cui, X.; Insarov, G.E.; Lasco, R.D.; Lindgren, E.; Surjan, A. Asia. In Climate Change 2014: Impacts, Adaptation, and Vulnerability. Part B: Regional Aspects. Contribution of Working Group II to the Fifth Assessment Report of the Intergovernmental Panel on Climate Change; Barros, V.R., Field, C.B., Dokken, D.J., Mastrandrea, M.D., Mach, K.J., Bilir, T.E., Chatterjee, M., Ebi, K.L., Estrada, Y.O., Genova, R.C., et al., Eds.; Cambridge University Press: Cambridge, UK, 2014; pp. $1327-1370$.

3. Reyer, C.P.O.; Otto, I.M.; Adams, S.; Albrecht, T.; Baarsch, F.; Cartsburg, M.; Coumou, D.; Eden, A.; Ludi, E.; Marcus, R.; et al. Climate Change Impacts in Central Asia and Their Implications for Development. Reg. Environ. Change 2017, 17, 1639-1650. [CrossRef]

4. Borgomeo, E.; Mortazavi-Naeini, M.; Hall, J.W.; Guillod, B.P. Risk, Robustness and Water Resources Planning Under Uncertainty. Earth's Future 2018, 6, 468-487. [CrossRef]

5. Shnitnikov, A.V. Water Balance Variability of Lakes Aral, Balkhash, Issyk-Kul and Chany. Hydrol. Lakes 1973, 19, 130-140. [CrossRef]

6. Nurtazin, S.; Thevs, N.; Iklasov, M.; Graham, N.; Salmurzauli, R.; Pueppke, S. Challenges to the Sustainable Use of Water Resources in the Ili River Basin of Central Asia. E3S Web Conf. 2019, 81, 01009. [CrossRef]

7. Thevs, N.; Nurtazin, S.; Beckmann, V.; Salmyrzauli, R.; Khalil, A. Water Consumption of Agriculture and Natural Ecosystems along the Ili River in China and Kazakhstan. Water 2017, 9, 207. [CrossRef]

8. Isupova, M.V. The Effects of the Ili River Runoff and Water Regulation Function of the Delta on the Changing Water Level of Balkhash Lake Depending on the Delta Forest Coverage. Water Resour. 2019, 46, S29-S42. [CrossRef]

9. Imentai, A.; Thevs, N.; Schmidt, S.; Nurtazin, S.; Salmurzauli, R. Vegetation, Fauna, and Biodiversity of the Ile Delta and Southern Lake Balkhash-A Review. J. Great Lakes Res. 2015, 41, 688-696. [CrossRef]

10. Guo, L.; Xia, Z.; Zhou, H.; Huang, F.; Yan, B. Hydrological Changes of the Ili River in Kazakhstan and the Possible Causes. J. Hydrol. Eng. 2015, 20, 05015006. [CrossRef] 
11. Li, D.; Zhao, L.; Wang, C.; Sun, W.; Xue, J. Selection of China's Imported Grain Distribution Centers in the Context of the Belt and Road Initiative. Transp. Res. Part. E Logist. Transp. Rev. 2018, 120, 16-34. [CrossRef]

12. Stone, R. For China and Kazakhstan, No Meeting of the Minds on Water. Science 2012, 337, 405-407. [CrossRef] [PubMed]

13. Ho, S. China's Transboundary River Policies towards Kazakhstan: Issue-Linkages and Incentives for Cooperation. Water Int. 2017, 42, 142-162. [CrossRef]

14. Pueppke, S.G.; Nurtazin, S.T.; Graham, N.A.; Qi, J. Central Asia's Ili River Ecosystem as a Wicked Problem: Unraveling Complex Interrelationships at the Interface of Water, Energy, and Food. Water 2018, 10, 541. [CrossRef]

15. Propastin, P. Patterns of Lake Balkhash Water Level Changes and Their Climatic Correlates during 1992-2010 Period. Lakes Reserv. Res. Manag. 2012, 17, 161-169. [CrossRef]

16. Pueppke, S.; Zhang, Q.; Nurtazin, S. Irrigation in the Ili River Basin of Central Asia: From Ditches to Dams and Diversion. Water 2018, 10, 1650. [CrossRef]

17. Martens, P. The Political Economy of Water Insecurity in Central Asia given the Belt and Road Initiative. Cent. Asian J. Water Res. 2018, 4, 79-94. [CrossRef]

18. Nabiyeva, K. Win-Win or Win-Lose? China-Kazakhstan Energy Cooperation within the Belt and Road Initiative. Blickwechsel 2019. [CrossRef]

19. Sternberg, T.; Ahearn, A.; McConnell, F. Central Asian 'Characteristics' on China's New Silk Road: The Role of Landscape and the Politics of Infrastructure. Land 2017, 6, 55. [CrossRef]

20. Toktomushev, K. Coronavirus and Sinophobia: Fear Along the Belt and Road. China-US Focus 2020. Available online: www. chinausfocus.com/energy-environment/coronavirus-and-sinophobia-fear-along-the-belt-androad (accessed on 1 June 2020).

21. Clarke-Sather, A. From the Heavens to the Markets: Governing Agricultural Drought under Chinese Fragmented Authoritarianism. Ann. Am. Assoc. Geogr. 2019, 109, 456-464. [CrossRef]

22. Chen, J.; Wu, H.; Qian, H.; Li, X. Challenges and Prospects of Sustainable Groundwater Management in an Agricultural Plain along the Silk Road Economic Belt, North-West China. Int. J. Water Resour. Dev. 2018, 34, 354-368. [CrossRef]

23. Qi, J.; Tao, S.; Pueppke, S.G.; Espolov, T.E.; Beksultanov, M.; Chen, X.; Cai, X. Changes in Land Use/Land Cover and Net Primary Productivity in the Transboundary Ili-Balkhash Basin of Central Asia, 1995-2015. Environ. Res. Commun. 2020, 2, 011006. [CrossRef]

24. Christiansen, T.; Schöner, U.; Giessen, J.; Gießen, D. Irrigation Areas and Irrigation Water Consumption in the Upper Ili Catchment, N-W China; Justus-Liebig-Universität Gießen, Zentrum für Internationale Entwicklungs- und Umweltforschung (ZEU): Giessen, Germany, 2004.

25. Grant, A. Crossing Khorgos: Soft Power, Security, and Suspect Loyalties at the Sino-Kazakh Boundary. Polit. Geogr. 2020, 76, 102070. [CrossRef]

26. World Bank Group Climate Change Knowledge Portal, For Development Practitioners and Policy Makers. 2020. Available online: https: / / climateknowledgeportal.worldbank.org/ (accessed on 1 July 2020).

27. Kogutenko, L.; Severskiy, I.; Shahgedanova, M.; Lin, B. Change in the Extent of Glaciers and Glacier Runoff in the Chinese Sector of the Ile River Basin between 1962 and 2012. Water 2019, 11, 1668. [CrossRef]

28. Shahgedanova, M.; Afzal, M.; Hagg, W.; Kapitsa, V.; Kasatkin, N.; Mayr, E.; Rybak, O.; Saidaliyeva, Z.; Severskiy, I.; Usmanova, Z.; et al. Emptying Water Towers? Impacts of Future Climate and Glacier Change on River Discharge in the Northern Tien Shan, Central Asia. Water 2020, 12, 627. [CrossRef]

29. Unger-Shayesteh, K.; Vorogushyn, S.; Farinotti, D.; Gafurov, A.; Duethmann, D.; Mandychev, A.; Merz, B. What Do We Know about Past Changes in the Water Cycle of Central Asian Headwaters? A Review. Glob. Planet. Change 2013, 110, 4-25. [CrossRef]

30. Xenarios, S.; Gafurov, A.; Schmidt-Vogt, D.; Sehring, J.; Manandhar, S.; Hergarten, C.; Shigaeva, J.; Foggin, M. Climate Change and Adaptation of Mountain Societies in Central Asia: Uncertainties, Knowledge Gaps, and Data Constraints. Reg. Environ. Change 2019, 19, 1339-1352. [CrossRef]

31. Duan, W.; Zou, S.; Chen, Y.; Nover, D.; Fang, G.; Wang, Y. Sustainable Water Management for Cross-Border Resources: The Balkhash Lake Basin of Central Asia, 1931-2015. J. Clean. Prod. 2020, 263, 121614. [CrossRef]

32. Prudhomme, C.; Wilby, R.L.; Crooks, S.; Kay, A.L.; Reynard, N.S. Scenario-Neutral Approach to Climate Change Impact Studies: Application to Flood Risk. J. Hydrol. 2010, 390, 198-209. [CrossRef]

33. Brown, C.; Steinschneider, S.; Ray, P.; Wi, S.; Basdekas, L.; Yates, D. Decision Scaling (DS): Decision Support for Climate Change. In Decision Making under Deep Uncertainty; Springer: Cham, Switzerland, 2019; pp. 255-287.

34. Conway, D.; Nicholls, R.J.; Brown, S.; Tebboth, M.G.L.; Adger, W.N.; Ahmad, B.; Biemans, H.; Crick, F.; Lutz, A.F.; De Campos, R.S.; et al. The Need for Bottom-up Assessments of Climate Risks and Adaptation in Climate-Sensitive Regions. Nat. Clim. Change 2019, 9, 503-511. [CrossRef]

35. Brown, C.; Ghile, Y.; Laverty, M.; Li, K. Decision Scaling: Linking Bottom-up Vulnerability Analysis with Climate Projections in the Water Sector. Water Resour. Res. 2012, 48. [CrossRef]

36. Hall, J.W.; Borgomeo, E.; Mortazavi-Naeini, M.; Wheeler, K. Water Resource System Modelling and Decision Analysis. In Water Science, Policy, and Management; Wiley: Hoboken, NJ, USA, 2019; pp. 257-273.

37. Guo, L.; Xia, Z. Temperature and Precipitation Long-Term Trends and Variations in the Ili-Balkhash Basin. Theor. Appl. Climatol. 2014, 115, 219-229. [CrossRef] 
38. Guo, Y.; Shen, Y. Agricultural Water Supply/Demand Changes under Projected Future Climate Change in the Arid Region of Northwestern China. J. Hydrol. 2016, 540, 257-273. [CrossRef]

39. Li, Y.; Wang, H.; Chen, Y.; Deng, M.; Li, Q.; Wufu, A.; Wang, D.; Ma, L. Estimation of Regional Irrigation Water Requirements and Water Balance in Xinjiang, China during 1995-2017. PeerJ 2020, 2020, e8243. [CrossRef]

40. Sala, R.; Deom, J.-M.; Aladin, N.V.; Plotnikov, I.S.; Nurtazin, S. Geological History and Present Conditions of Lake Balkhash. Large Asian Lakes Chang. World 2020, 143-175. [CrossRef]

41. Vologdin, N.V. The Kapchagai hydroelectric Station On The Ili River*. Gidrotekhnicheskoe Stroitel'stvo 1972, 5, 1-7. [CrossRef]

42. Guanghua, H.; Long, Y. Study on Accelerating the Construction of Irrigation Districts in the Ili River Basin of Xinjiang. [Translated from Chinese]. China Surv. Des. Technol. Exch. 2007, 77-81.

43. Ili Prefecture Government Office. Ili Prefecture Master Plan for Direct Ecological Environmental Protection in Yili Prefecture; Ili Prefecture Government Office: Yining, Xinjiang, China, 2015.

44. Ouarda, T.B.M.J.; Labadie, J.W.; Fontane, D.G. Indexed Sequential Hydrologic Modeling For Hydropower Capacity Estimation. J. Am. Water Resour. Assoc. 1997, 33, 1337-1349. [CrossRef]

45. Hirpa, F.A.; Dyer, E.; Hope, R.; Olago, D.O.; Dadson, S.J. Finding Sustainable Water Futures in Data-Sparse Regions under Climate Change: Insights from the Turkwel River Basin, Kenya. J. Hydrol. Reg. Stud. 2018, 19, 124-135. [CrossRef]

46. Thomas, H.A. Improved Methods for National Water Assessment: Final Report; Water Resources Contract WR15249270; Harvard University: Cambridge, MA, USA, 1981; p. 44.

47. Martinez, G.F.; Gupta, H.V. Toward Improved Identification of Hydrological Models: A Diagnostic Evaluation of the "Abcd" Monthly Water Balance Model for the Conterminous United States. Water Resour. Res. 2010, 46. [CrossRef]

48. Ray, P.A.; Brown, C.M. Confronting Climate Uncertainty in Water Resources Planning and Project Design: The Decision Tree Framework; The World Bank: Washington, DC, USA, 2015.

49. Moriasi, D.N.; Arnold, J.G.; Van Liew, M.W.; Bingner, R.L.; Harmel, R.D.; Veith, T.L. Model Evaluation Guidelines for Systematic Quantification of Accuracy in Watershed Simulations. Trans. ASABE 2007, 50, 885-900. [CrossRef]

50. Zagona, E.A.; Fulp, T.J.; Shane, R.; Magee, T.; Goranflo, H.M. RiverWare: A Generalized Tool For Complex Reservoir System Modeling. JAWRA J. Am. Water Resour. Assoc. 2001, 37, 913-929. [CrossRef]

51. Wheeler, K.G.; Basheer, M.; Mekonnen, Z.T.; Eltoum, S.O.; Mersha, A.; Abdo, G.M.; Zagona, E.A.; Hall, J.W.; Dadson, S.J. Cooperative Filling Approaches for the Grand Ethiopian Renaissance Dam. Water Int. 2016, 41, 611-634. [CrossRef]

52. Basheer, M.; Wheeler, K.G.; Ribbe, L.; Majdalawi, M.; Abdo, G.; Zagona, E.A. Quantifying and Evaluating the Impacts of Cooperation in Transboundary River Basins on the Water-Energy-Food Nexus: The Blue Nile Basin. Sci. Total Environ. 2018, 630, 1309-1323. [CrossRef]

53. Wheeler, K.G.; Hall, J.W.; Abdo, G.M.; Dadson, S.J.; Kasprzyk, J.R.; Smith, R.; Zagona, E.A. Exploring Cooperative Transboundary River Management Strategies for the Eastern Nile Basin. Water Resour. Res. 2018, 54, 9224-9254. [CrossRef]

54. Wurbs, R.A. Methods for Developing Naturalized Monthly Flows at Gaged and Ungaged Sites. J. Hydrol. Eng. 2006, 11, 55-64. [CrossRef]

55. Shen, Y.; Li, S.; Chen, Y.; Qi, Y.; Zhang, S. Estimation of Regional Irrigation Water Requirement and Water Supply Risk in the Arid Region of Northwestern China 1989-2010. Agric. Water Manag. 2013, 128, 55-64. [CrossRef]

56. Grey, D.; Sadoff, C.W. Sink or Swim? Water Security for Growth and Development. Water Policy 2007, 9, 545-571. [CrossRef]

57. Garrick, D.; Hall, J.W. Water Security and Society: Risks, Metrics, and Pathways. Annu. Rev. Environ. Resour. 2014, 39, 611-639. [CrossRef]

58. Huizar, L.H.; Lansey, K.E.; Arnold, R.G. Sustainability, Robustness, and Resilience Metrics for Water and Other Infrastructure Systems. Sustain. Resilient Infrastruct. 2018, 3, 16-35. [CrossRef]

59. Baizakova, Z. Voices from Central Asia The Irtysh and Ili Transboundary Rivers: The Kazakh-Chinese Path to Compromise. Voices Cent. Asia 2015, 21, 1-12.

60. Hall, J.W.; Borgomeo, E.; Bruce, A.; Di Mauro, M.; Mortazavi-Naeini, M. Resilience of Water Resource Systems: Lessons from England. Water Secur. 2019, 8, 100052. [CrossRef]

61. Dostaj, Z.D.; Giese, E.; Hagg, W. Wasserressourcen Und Deren Nutzung Im Ili-Balchasch Becken; Discussion Paper 34; Justus-LiebigUniversität Gießen, Zentrum für Internationale Entwicklungs- und Umweltforschung (ZEU): Giessen, Germany, 2007.

62. Petr, T. Lake Balkhash, Kazakhstan. Int. J. Salt Lake Res. 1992, 1, 21-46. [CrossRef]

63. Hashimoto, T.; Stedinger, J.R.; Loucks, D.P. Reliability, Resiliency, and Vulnerability Criteria for Water Resource System Performance Evaluation. Water Resour. Res. 1982, 18, 14-20. [CrossRef]

64. Isbekov, K.B.; Tsoy, V.N.; Crétaux, J.F.; Aladin, N.V.; Plotnikov, I.S.; Clos, G.; Berge-Nguyen, M.; Assylbekova, S.Z. Impacts of Water Level Changes in the Fauna, Flora and Physical Properties over the Balkhash Lake Watershed. Lakes Reserv. Res. Manag. 2019, 24, 195-208. [CrossRef]

65. Panyushkina, I.P.; Meko, D.M.; Macklin, M.G.; Toonen, W.H.J.; Mukhamadiev, N.S.; Konovalov, V.G.; Ashikbaev, N.Z.; Sagitov, A.O. Runoff Variations in Lake Balkhash Basin, Central Asia, 1779-2015, Inferred from Tree Rings. Clim. Dyn. 2018, 51,3161-3177. [CrossRef]

66. Panyushkina, I.P.; Macklin, M.G.; Toonen, W.H.J.; Meko, D.M. Water Supply and Ancient Society in the Lake Balkhash Basin: Runoff Variability along the Historical Silk Road. In Socio-Environmental Dynamics along the Historical Silk Road; Yang, L.E., Bork, H.-R., Fang, X., Mischke, S., Eds.; Springer: Cham, Switzerland, 2019; pp. 379-410. 
67. Matsuyama, H.; Kezer, K. Long-Term Variation of Precipitation around Lake Balkhash in Central Asia from the End of the 19th Century. Sci. Online Lett. Atmos. 2009. [CrossRef]

68. Sorg, A.; Bolch, T.; Stoffel, M.; Solomina, O.; Beniston, M. Climate Change Impacts on Glaciers and Runoff in Tien Shan (Central Asia). Nat. Clim. Change 2012. [CrossRef]

69. Farinotti, D.; Longuevergne, L.; Moholdt, G.; Duethmann, D.; Mölg, T.; Bolch, T.; Vorogushyn, S.; Güntner, A. Substantial Glacier Mass Loss in the Tien Shan over the Past 50 Years. Nat. Geosci. 2015. [CrossRef]

70. Bolch, T. Climate Change and Glacier Retreat in Northern Tien Shan (Kazakhstan/Kyrgyzstan) Using Remote Sensing Data. Glob. Planet. Change 2007, 56, 1-12. [CrossRef]

71. Huss, M.; Hock, R. Global-Scale Hydrological Response to Future Glacier Mass Loss. Nat. Clim. Change 2018, 8, 135-140. [CrossRef]

72. Aizen, V.B.; Kuzmichenok, V.A.; Surazakov, A.B.; Aizen, E.M. Glacier Changes in the Tien Shan as Determined from Topographic and Remotely Sensed Data. Glob. Planet. Change 2007, 56, 328-340. [CrossRef]

73. Jimenez Cisneros, B.E.; Oki, T.; Arnell, N.W.; Benito, G.; Cogley, J.G.; Doll, P.; Jiang, T.; Mwakalila, S.S.; Fischer, T.; Gerten, D.; et al. Freshwater resources. In Climate Change 2014: Impacts, Adaptation and Vulnerability. Part A: Global and Sectoral Aspects. Contribution of Working Group II to the Fifth Assessment Report of the Intergovernmental Panel on Climate Change; Field, C.B., Barros, V.R., Dokken, D.J., Mastrandrea, M.D., Mach, K.J., Bilir, T.E., Chatterjee, M., Ebi, K.L., Estrada, Y.O., Genova, R.C., et al., Eds.; Intergovernmental Panel on Climate Change; Cambridge University Press: Cambridge, UK, 2014; pp. 229-269.

74. Wheeler, K.G.; Robinson, C.J.; Bark, R.H. Modelling to Bridge Many Boundaries: The Colorado and Murray-Darling River Basins. Reg Environ. Change 2018, 18, 1607-1619. [CrossRef]

75. Brown, C. The End of Reliability. J. Water Resour. Plan. Manag. 2010, 136, 143-145. [CrossRef] 